\title{
Assessment of the Components and Sources of Acid Deposition in Northeast Asia: A Case Study of the Coastal and Metropolitan Cities in Northern Taiwan
}

\author{
Hung-Yu Chen ${ }^{1, * \mathbb{D}}$, Ling-Fei Hsu ${ }^{1}$, Shih-Zhe Huang ${ }^{1}$ and Long Zheng ${ }^{2}$ \\ 1 Department of Marine Environmental Informatics, National Taiwan Ocean University, Keelung 202, Taiwan; \\ anitahsu@envimac.com.tw (L.-F.H.); benson50705@gmail.com (S.-Z.H.) \\ 2 Global-Analyst Co. Ltd., 3F., No. 766, Zhongzheng Rd., Zhonghe Dist., New Taipei City 235, Taiwan; \\ jslsolomon@gmail.com \\ * Correspondence: hychen@mail.ntou.edu.tw
}

Received: 30 July 2020; Accepted: 8 September 2020; Published: 14 September 2020

\begin{abstract}
In this study, temporal variations, major ion reference indexes, correlation analysis, and statistical data were used to investigate the chemical characteristics of the atmospheric pollutants in wet deposition and reasons for their formation, and further insight into the impact of local and regional atmospheric pollutant distributions on urban and coastal area environments. From November 2014 to October 2015, 158 rainwater samples were collected in coastal Wanli and urban Banqiao of southern Northeast Asia (northern Taiwan). The mean $\mathrm{pH}$ of the coastal and urban was 4.63 and 4.58, respectively, lower than the mean (5.31) of 10 East Asia regions during the year of 2015. This was possibly because the concentration of the combined $\mathrm{SO}_{4}{ }^{2-}$ and $\mathrm{NO}_{3}{ }^{-}$in the study area were greater than the mean of the 10 East Asian regions. This is verified by the calculation of sea-salt fraction (SSF) and non-SSF fraction (NSSF) in study areas, which indicated that $\mathrm{Na}^{+}$and $\mathrm{Cl}^{-}$accounted for over $85 \%$ of the SSF, without $\mathrm{Na}^{+}$in Banqiao, were mainly due to marine sources. For the NSSF, in addition to $\mathrm{SO}_{4}{ }^{2-}$ in Wanli, nearly $90 \%$ of wet disposition was from $\mathrm{SO}_{4}{ }^{2-}$ and $\mathrm{NO}_{3}{ }^{-}$, which were emitted from human activities. Furthermore, the analysis of fractional acidity (FA), neutralization factors (NF), neutralization potential (NP), and acidification potential (AP) revealed that acidified precipitation was caused by a lack of neutralizing compounds, which resulted in less neutralization of acidic precipitation. Finally, the results of correlation and principal component analysis (PCA) indicated that because coastal area were geographically closer to the ocean, wet deposition mainly comes from marine sources. However, in urban with a high population density and high traffic quantity, the ions in wet deposition primarily come from anthropogenic activities, such as industrial combustion and vehicle emissions.
\end{abstract}

Keywords: acid rain; wet deposition; major ion reference indexes; enrichment factor; correlation and principal component analysis

\section{Introduction}

Industrialization, traffic development, and population concentration in urban areas have caused severe air pollution problems and affected the health and environmental quality of residents who live in cities and nearby areas. Air pollution, atmospheric aerosols, and precipitation acidification are common phenomena that are interrelated [1]. Air pollutants are accumulated or removed through atmospheric dry and wet deposition. Wet deposition is the primary mechanism for scavenging gas and particle phase pollutants in the atmosphere [2]. This process is crucial for the nutrient cycle and for scavenging pollutants from the surrounding air. Other than air pollution sources from human activities, 
the environmental background of a city (such as its location in a basin or near the coast) can affect the distribution of air pollutants and their behavior in the environment. Kulshrestha et al. (2003) [3] indicated that the chemical properties and characteristics of precipitation differ across regions or sites on the basis of particulates being emitted into the ecological system by humans or natural phenomena. Generally, exploring precipitation sources and transmission is primarily based on the concentration of major dissolved ions in the precipitation, the ion concentration from natural and anthropogenic sources, and the stoichiometry between ions [4].

The chemical component of precipitation can reveal important information on the level of pollution and help assess acidifying, neutralizing, and eutrophying species in the atmosphere and the deposition and transportation of heavy metal and aerosols [5]. Urbanization and human activities have a major impact on the chemical component of precipitation. Because the emission sources of these pollutants are complex (they undergo many physical and chemical mechanisms before being deposited as rain), research on the chemical components of precipitation can provide valuable air quality information and assist with differentiating pollution sources [6]. In the past 30 years, countries across the globe have conducted studies on precipitation chemistry to determine the source of precipitation according to its chemical components, thereby gaining a further insight into the partial and regional distribution of pollutants and the potential impact of scavenging and deposition in the environment [7].

Acid rain has been among the greatest environmental problems in the last few decades of the 20th century, particularly in the 1980s, when most people believed that acid rain was one of the greatest environmental threats of the time. The danger from acid rain is slow, and only when Europe and North America discovered the precipitation acidification phenomenon did scientists pay attention to this problem [8]. Acid rain is mainly produced from the emission of a large quantity of sulfur dioxide $\left(\mathrm{SO}_{2}\right)$ and reactive nitrogen oxide $\left(\mathrm{NO}_{x}\right)$ in human activities, which causes the gradual acidification of the atmospheric and ecological environments. Chen and Chen (2008) [9] noted that in the 1990s, the economy and population in East Asia grew rapidly. The region became highly urbanized and induced changes in farming patterns. Industrial development and petroleum fuel use increased, and the air pollution problem in the region became more severe. The main species that caused acid rain in the two megacities in China (Shanghai and Shenzhen) were sulfates and nitrates $[6,10]$. The study results revealed that rapid economic development caused the increased emission of acidic substances, which was the main reason for the acidification of precipitation.

Smith (1872) [11] analyzed the chemical component of precipitation in the industrial city of Manchester and its surrounding areas and discovered that the city's precipitation contained sulfuric acid $\left(\mathrm{H}_{2} \mathrm{SO}_{4}\right)$ or acidic sulfuric acid salts $\left(\mathrm{SO}_{4}{ }^{2-}\right)$, which made the precipitation acidic. Precipitation in the suburban areas contained ammonium sulfate $\left(\left(\mathrm{NH}_{4}\right)_{2} \mathrm{SO}_{4}\right)$ and was slightly acidic. However, precipitation from rural farm villages contained ammonium carbonate $\left(\left(\mathrm{NH}_{4}\right)_{2} \mathrm{CO}_{3}\right)$ and was only mildly acidic [12]. Generally, spatial differences directly affect the chemical properties of wet deposition. Continental wet deposition has a higher concentration of man-made ions than neutral marine rain, particularly when it comes to acidic material in urban and rural atmospheric precipitation. Thus, acid rain has become a global environmental problem [1]. Changes in the ion concentration in wet deposition are notably related to the source of the air mass, particularly when the air mass source contains other non-sea-salt sources (such as sand dust, biomass burning, and fossil fuel combustion). Some ion concentrations increase because of the special characteristics of the source. According to such characteristics, the main ion concentration can be used to determine the main sources of the aerosol [4].

Taiwan is located at the junction of the Eurasian continent and the Pacific Ocean, and its climate is affected by the interaction of continental and marine climate patterns. In the winter, continental cold high pressure comes from Siberia as northeast monsoon winds. In the summer, the Pacific marine high pressure comes as southwest monsoon winds. The main rainy season runs from May to June, and the typhoon season runs from July to September. Taiwan's geographical location is downwind of continental pollutant emissions, which has a significant impact on the wet deposition composition. In northern Taiwan, the historic wet deposition $\mathrm{pH}$ is lower than 5.0, particularly during the northeast 
monsoon wind season. The higher concentration of acid pollutants from the continent renders acid rain more severe during the winter than during the summer. Therefore, acid rain is influenced by climate patterns and exhibits seasonal characteristics. Chen and Chen (2008) [9] noted that the region's atmospheric deposition is mainly affected by sea salt, biomass burning, and fossil fuel combustion.

In this study, data were acquired from precipitation samples collected by two wet deposition sampling stations in the southern part of Northeast Asia (Wanli and Banqiao in northern Taiwan) for 12 months. The chemical components of the samples were analyzed, and the results were used to understand the chemical properties of atmospheric pollutants in wet deposition and the reason for their formation. To achieve the research objective, several research methods were adopted for comprehensive analysis, namely $\mathrm{pH}$ measurement, ion composition analysis, major ion reference indexes, and correlation coefficient and principle component analysis (PCA). In addition, the wet deposition survey results for the East Asia regions in the Acid Deposition Monitoring Network in East Asia (EANET) (2015) [13] report were referenced to verify the effects of possible air pollution sources on urban and coastal city environments as well as the differences of effects.

\section{Methodology}

\subsection{Sampling Location and Sample Analysis}

In this study, rainwater samples were collected from two sampling stations (Figure 1), which are located in Wanli $\left(25^{\circ} 11^{\prime} 56^{\prime \prime} \mathrm{N} ; 1^{\circ} 1^{\circ} 38^{\prime} 48^{\prime \prime} \mathrm{E}\right)$ and Banqiao $\left(25^{\circ} 0^{\prime} 44^{\prime \prime} \mathrm{N} ; 1^{\circ} 1^{\circ} 27^{\prime} 22^{\prime \prime} \mathrm{E}\right)$. These two rainwater sampling stations were operated and maintained by the Department of Environmental Protection, New Taipei City Government. Wanli is located on the southern margin of the East China Sea and in the northeast coast of Taiwan. This area is surrounded by mountains on three sides and the other is facing the sea. Human activities in this area are relatively small and are mainly affected by the ocean. The average annual temperature is $21.9^{\circ} \mathrm{C}$, and the annual rainfall is approximately $2900 \mathrm{~mm}$. The wet and dry seasons in the region are from October to March and June to September, respectively. Banqiao is the capital city of New Taipei City with a population of 554,000. The city has 527 industrial factories and 450,000 motor vehicles. The average annual temperature in Banqiao is $23{ }^{\circ} \mathrm{C}$, and the average annual rainfall is $2405 \mathrm{~mm}$. Rainfall mainly occurs from May to September. This study used the area of Wanli as the background station and Banqiao as an urban monitoring station that is affected by anthropogenic activities to compare the differences of acid rain properties in urban areas and coastal cities.

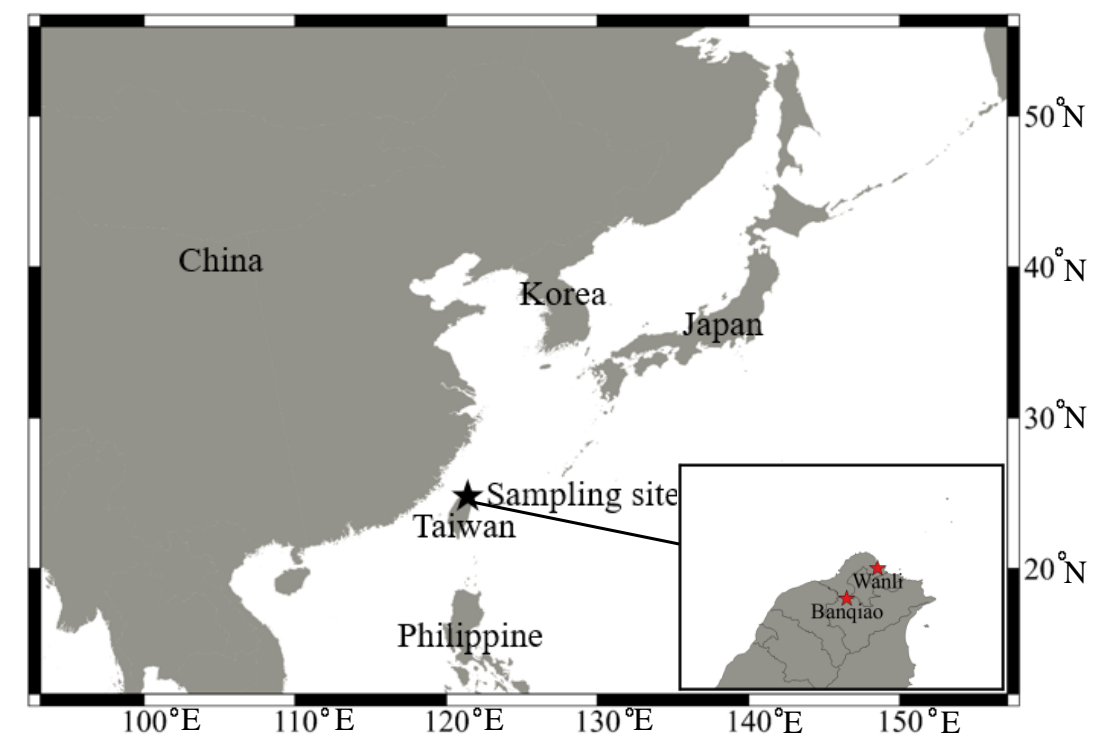

Figure 1. Map of the study area, sampling sites. 
In this study, 158 wet deposition samples (99 for Wanli and 59 for Banqiao) including 7 typhoon samples (4 for Wanli and 3 for Banqiao) were collected during the period from September 2014 to October 2015. Wet deposition was collected using the acid precipitation sampler (TE-78-100, Tisch Environmental, Cleves, OH, USA). The precipitation sampler automatically collected precipitation samples every time rainfall occurred. The day after the rain event, the samples were collected on site at 9:00 $\pm 0.5 \mathrm{hr}$. Samples that contained less than $150 \mathrm{~mL}$ of rainwater were excluded from the study because the amount was insufficient for experiments and analysis. The $\mathrm{pH}$ meter (WTW pH3310; Suntex Instruments Co., Taiwan) uses glass electrodes and references the electrical potential of tested samples by using electrodes to determine the activity of hydrogen ions. The device has an automatic or manual temperature compensation function and can read to $0.01 \mathrm{pH}$. The rainwater sample was initially filtered using a pre-ashed quartz fiber membrane (Quartz fiber membrane, QR-100, $24 \mathrm{~mm}$, Advantec, Japan). The filtered samples were then poured into brown glass bottles, which were sealed with parafilms before being stored in a refrigerator at $4{ }^{\circ} \mathrm{C}$. The samples were analyzed within a week and were stored for a maximum of three weeks to reduce the likelihood of chemical composition changes [4].

After preprocessing, the cations and anions of the precipitation in the samples were analyzed using ion chromatography (Dionex-Ultimate 3000, Thermo Fisher Scientific, Waltham, MA, USA). An IonPac AS12A column was used for the anions, and an ASRS-300 was used as the suppressor. The eluent was a mixture of $2.7 \mathrm{mM}$ of sodium carbonate $\left(\mathrm{Na}_{2} \mathrm{CO}_{3}\right) / 0.3 \mathrm{mM}$ of sodium bicarbonate $\left(\mathrm{NaHCO}_{3}\right)$, and the eluent flow was $1.5 \mathrm{~mL} \mathrm{~min}^{-1}$. An IonPac CS12A column was used for the cation, and a CSRS-300 was used as the suppressor. The eluent was $20 \mathrm{mM}$ of methanesulfonic acid, and the eluent flow was $1.0 \mathrm{~mL} \mathrm{~min}^{-1}$. In this study, analysis of the primary ions in the precipitation included the anion concentration $\left(\mathrm{Cl}^{-}, \mathrm{NO}_{3}{ }^{-}\right.$, and $\left.\mathrm{SO}_{4}{ }^{2-}\right)$ and cation concentration $\left(\mathrm{NH}_{4}{ }^{+}, \mathrm{Na}^{+}, \mathrm{K}^{+}, \mathrm{Mg}^{2+}\right.$, and $\mathrm{Ca}^{2+}$ ). For more details, please reference Chen et al. (2015) [4]. The relative percent difference for all ion analyses was $4.26 \pm 2.41 \%$.

\subsection{Quality Assurance Measures}

In addition to the ion chromatography of primary cations and anions, the $\mathrm{H}^{+}, \mathrm{OH}^{-}$, and $\mathrm{HCO}_{3}^{-}$ ions in wet deposition were calculated using the following equation based on the measured $\mathrm{pH}$ level:

$$
\begin{gathered}
{\left[\mathrm{H}^{+}\right]=10^{-\mathrm{pH}}} \\
{\left[\mathrm{OH}^{-}\right]=10^{\mathrm{pH}-14}} \\
{\left[\mathrm{HCO}_{3}^{-}\right]=10^{-11.24+\mathrm{pH}}}
\end{gathered}
$$

where $\left[\mathrm{H}^{+}\right],\left[\mathrm{OH}^{-}\right]$, and $\left[\mathrm{HCO}_{3}{ }^{-}\right]$are the molar concentration $(\mathrm{mol} / \mathrm{L})$ and the equivalent concentration of $\mathrm{H}^{+}, \mathrm{OH}^{-}$, and $\mathrm{HCO}_{3}{ }^{-}$, respectively (because the electrical charge is from a single valence electron; $\mathrm{eq} / \mathrm{L})$.

In addition, determining the anion and cation electrical charge balance required the calculation of the sum of the anions $\left(\Sigma \mathrm{TZ}^{-}\right)$and cations $\left(\Sigma \mathrm{TZ}^{+}\right)$. The sums were calculated from the following equations, respectively:

$$
\begin{gathered}
\Sigma \mathrm{TZ}^{-}=\left[\mathrm{HCO}_{3}{ }^{-}\right]+\left[\mathrm{OH}^{-}\right]+2\left[\mathrm{SO}_{4}{ }^{2-}\right]+\left[\mathrm{NO}_{3}{ }^{-}\right]+\left[\mathrm{Cl}^{-}\right] \\
\Sigma \mathrm{TZ}^{+}=\left[\mathrm{H}^{+}\right]+2\left[\mathrm{Ca}^{2+}\right]+2\left[\mathrm{Mg}^{2+}\right]+\left[\mathrm{Na}^{+}\right]+\left[\mathrm{K}^{+}\right]+\left[\mathrm{NH}_{4}{ }^{+}\right]
\end{gathered}
$$

The ion concentration unit is $\mu \mathrm{mol} / \mathrm{L}$, and the $\Sigma \mathrm{TZ}^{-}$and $\Sigma \mathrm{TZ}^{+}$concentration unit is $\mu \mathrm{eq} / \mathrm{L}$. The $\Sigma \mathrm{TZ}^{-} / \Sigma \mathrm{TZ}^{+}$ratio was within the $1 \pm 0.25$ scope. Thus, the scope of the data was acceptable [14]. 


\subsection{Major Ion Reference Indexes}

\subsubsection{Enrichment Factor (EF) and Source Fraction}

Marine and crustal enrichment factor $\left(\mathrm{EF}_{\mathrm{m}}\right.$ and $\left.\mathrm{EFs}\right)$ are often used to identify whether the ions in precipitation are derived from marine or crustal sources. Marine enrichment factor $\left(\mathrm{EF}_{\mathrm{m}}\right)$ uses $\mathrm{Na}^{+}$as the indicator ion for marine sources [15]. Crustal enrichment factor $\left(\mathrm{EF}_{\mathrm{c}}\right)$ uses $\mathrm{Ca}^{2+}$ as the indicator ion for crustal sources [16]. The calculation method for EFs are shown as follows:

$$
\begin{aligned}
& \mathrm{EF}_{\mathrm{m}}=\frac{\left[\frac{\mathrm{X}}{\mathrm{Na}^{+}}\right]_{\text {rain }}}{\left[\frac{\mathrm{X}}{\mathrm{Na}^{+}}\right]_{\text {sea }}} \\
& \mathrm{EF}_{\mathrm{C}}=\frac{\left[\frac{\mathrm{x}}{\mathrm{Ca}^{2+}}\right]_{\text {rain }}}{\left[\frac{\mathrm{X}}{\mathrm{Ca}^{2+}}\right]_{\text {crust }}}
\end{aligned}
$$

where $\left[\mathrm{X} / \mathrm{Na}^{+}\right]_{\text {rain }} /\left[\mathrm{X} / \mathrm{Na}^{+}\right]_{\text {sea }}$ is the $\mathrm{X}$ ion concentration and $\mathrm{Na}^{+}$concentration ratio in the precipitation sample and seawater, and $\left[\mathrm{X} / \mathrm{Ca}^{2+}\right]_{\text {rain }} /\left[\mathrm{X} / \mathrm{Ca}^{2+}\right]_{\text {crust }}$ is the $\mathrm{X}$ ion concentration and $\mathrm{Ca}^{2+}$ concentration ratio in the precipitation sample and crust. In this study, the $\left[\mathrm{X} / \mathrm{Na}^{+}\right]_{\text {sea }}$ and $\left[\mathrm{X} / \mathrm{Ca}^{2+}\right]_{\text {crust }}$ ratio was referenced from $[14,17]$.

Furthermore, to determine the possible sources of precipitation, this study divided such sources into seawater, crustal, and anthropogenic sources. The following equations are used to calculate their fractions, respectively $[14,18,19]$ :

$$
\begin{gathered}
\mathrm{SSF}(\%)=\frac{\left[\frac{\mathrm{X}}{\mathrm{Na}^{+}}\right]_{\text {sea }} \times\left[\mathrm{Na}^{+}\right]_{\text {rain }}}{[\mathrm{X}]_{\text {rain }}} \times 100=\frac{1}{\mathrm{EF}_{\mathrm{m}}} \times 100 \\
\mathrm{CF}(\%)=\frac{\left[\frac{\mathrm{X}}{\mathrm{Ca}^{2+}}\right]_{\text {crust }} \times\left[\mathrm{Ca}^{2+}\right]_{\text {rain }}}{[\mathrm{X}]_{\text {rain }}} \times 100=\frac{1}{\mathrm{EF}_{\mathrm{C}}} \times 100 \\
\mathrm{AF}(\%)=100-\mathrm{SSF}-\mathrm{CF}
\end{gathered}
$$

where SSF, CF, and AF represent the sea-salt fraction (SSF), crustal fraction (CF), and anthropogenic fraction $(\mathrm{AF})$, respectively. $[X]_{\text {rain }}$ is the $X$ ion concentration $(\mu \mathrm{mol} / \mathrm{L})$ in the precipitation, and $\left[\mathrm{Na}^{+}\right]_{\text {rain }}$ and $\left[\mathrm{Ca}^{2+}\right]_{\text {rain }}$ are the $\mathrm{Na}^{+}$and $\mathrm{Ca}^{2+}$ concentration $(\mu \mathrm{mol} / \mathrm{L})$ in the precipitation, respectively.

Strong acids from anthropogenic emissions $\left(\mathrm{H}_{2} \mathrm{SO}_{4}\right.$ and $\left.\mathrm{HNO}_{3}\right)$ are the main impact factors in wet deposition acidity. Sulfates can be produced from anthropogenic or seawater sources. Thus, when exploring anthropogenic sulfates, seawater sulfates must first be deducted. This results in anthropogenic sulfates or non-sea-salt sulfates $\left(\mathrm{nss}-\mathrm{SO}_{4}{ }^{2-}\right)$. The following equation is used for calculation:

$$
\begin{aligned}
& {\left[\mathrm{nss}^{-\mathrm{SO}_{4}^{2-}}\right]=\left[\mathrm{SO}_{4}^{2-}\right]-0.06 \times\left[\mathrm{Na}^{+}\right]} \\
& {\left[\mathrm{nss}^{+} \mathrm{Ca}^{2+}\right]=\left[\mathrm{Ca}^{2+}\right]-0.02 \times\left[\mathrm{Na}^{+}\right]}
\end{aligned}
$$

where $\left[\right.$ nss- $\left.\mathrm{SO}_{4}{ }^{2-}\right]$ and $\left[\mathrm{nss}-\mathrm{SO}_{4}{ }^{2-}\right]$ are the concentration $(\mu \mathrm{mol} / \mathrm{L})$ of non-sea-salt sulfates and non-sea-salt calcium, respectively; and $\left[\mathrm{Na}^{+}\right],\left[\mathrm{SO}_{4}{ }^{2-}\right]$, and $\left[\mathrm{Ca}^{2+}\right]$ are the concentration $(\mu \mathrm{mol} / \mathrm{L})$ of $\mathrm{Na}^{+}, \mathrm{SO}_{4}{ }^{2-}$, and $\mathrm{Ca}^{2+}$ in wet deposition.

In wet deposition, nss- $\mathrm{SO}_{4}{ }^{2-}$ and $\mathrm{NO}_{3}{ }^{-}$are the two main acidic components. Thus, fractional acidity (FA) can be used to assess the level of acid neutralization in wet deposition. The FA estimation equation is as follows:

$$
\mathrm{FA}=\frac{\left[\mathrm{H}^{+}\right]}{\left[\mathrm{NO}_{3}^{-}\right]+\left[\mathrm{nss}^{-\mathrm{SO}_{4}^{2-}}\right]}
$$


If FA equals 1, wet deposition cannot neutralize the acidity produced by $\mathrm{H}_{2} \mathrm{SO}_{4}$ and $\mathrm{HNO}_{3}$ [20]. In wet deposition, the ionizing acidity produced by nss- $-\mathrm{SO}_{4}{ }^{2-}$ and $\mathrm{NO}_{3}{ }^{-}$can be buffered using $\mathrm{NH}_{4}{ }^{+}, \mathrm{Ca}^{2+}, \mathrm{K}^{+}$, and $\mathrm{Mg}^{2+}$. Quantifying the neutralization factor (NF) can indicate the availability of these cations to neutralize free acid in rainwater $[15,21]$ :

$$
\begin{aligned}
\mathrm{NF}_{\left(\mathrm{X}^{+}\right)} & =\frac{\left[\mathrm{X}^{+}\right]}{\left[\mathrm{NO}_{3}^{-}\right]+2\left[\mathrm{nss}^{\left.-\mathrm{SO}_{4}^{2-}\right]}\right.} \\
\mathrm{NF}_{\left(\mathrm{X}^{2+}\right)} & =\frac{\left[\mathrm{X}^{2+}\right]}{2\left[\mathrm{NO}_{3}^{-}\right]+\left[\mathrm{nss}_{-} \mathrm{SO}_{4}^{2-}\right]}
\end{aligned}
$$

The ratio of neutralization potential (NP) to acidification potential (AP) is used to evaluate the balance between acidity and alkalinity and is calculated with the following equation [22]:

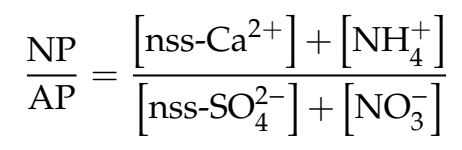

To assess the availability of ammonia to neutralize the acidic substances $\mathrm{H}_{2} \mathrm{SO}_{4}$ and $\mathrm{HNO}_{3}$ in the atmosphere, an ammonium availability index (AAI) was defined. The AAI uses the molar ratio expression to determine the ammonia concentration that is required to completely neutralize sulfuric acid and nitric acid $[23,24]$ :

$$
\mathrm{AAI}=\frac{\left[\mathrm{NH}_{4}^{+}\right]}{2 \times\left[\mathrm{SO}_{4}^{2-}\right]+\left[\mathrm{NO}_{3}^{-}\right]} \times 100 \%
$$

An AAI of $<100 \%$ indicates a lack of ammonia to fully neutralize sulfates and nitrates acids. If $\mathrm{AAI}=100 \%$, the sulfates and nitrates are completely neutralized. If the AAI $>100 \%$, the ammonia is sufficient to neutralize the sulfuric acid and nitric acid.

\subsubsection{Correlation and Principal Component Analysis}

The correlation analysis in this study entailed the use of the Pearson product-moment correlation coefficient, which is often abbreviated as Pearson's $r$. This coefficient ranges between 1 and -1 and is calculated as the covariance and standard deviation quotient between two variables [25]. When the two variables are positively correlated, the correlation coefficient is greater than 0 . If the two variables are negatively correlated, the correlation coefficient is less than 0 . When the correlation coefficient is 0 , the two variables have no correlation. The closer the correlation coefficient absolute value is to 1 , the higher the correlation between the two variables becomes.

Principal component analysis (PCA) is a multivariate statistical analysis method. In PCA, the coordinate axis center is shifted to align with the center of data. Next, the coordinate axis is rotated to maximize the variance of the newly synthesized variables variance following projection (the broadest data distribution on the coordinate axis). This projected linear combination is the first main component and consists of the maximum eigenvalue in the covariance matrix of the variable. The second largest projected variance is the second main component, and so on. If a set of data has $n$ variables, PCA can determine $n$ main components. These main components (eigenvectors) must be orthogonal [26]. The percentage of explained variance for each main component is the main component's eigenvalue divided by the total eigenvalues of all main components. A loading denotes the coefficient that describes changes in variables. A greater loading results in a greater impact of the original variable on the new variable. The size of a loading is often used to define the meaning of a main component, and whether it is positive or negative is irrelevant for the main component and only has an impact on the correlation between species. If they are both positive or negative, a positive 
correlation is present. By contrast, if they are different, a negative correlation is present [9]. In this study, IBM's Statistical Product and Service Solutions v12.0 was used for the correlation and PCA.

\section{Results and Discussion}

\subsection{Variation of $\mathrm{pH}$ and Chemical Composition of Rainwater}

Overall, $71.7 \%$ and $85.7 \%$ of the samples from Wanli (coastal) and Banqiao (urban), respectively, had a $\mathrm{pH}$ value lower than 5 (the means were 4.63 and 4.58, respectively). This indicated that precipitation in the sampling area had a higher level of acidity. The $\mathrm{pH}$ values of rainwater in Wanli and Banqiao were showed a clear seasonal variation which was none more than $\mathrm{pH} 5$ and minimum value in the winter, and further, up to $71.3 \%(\mathrm{pH}>5)$ in the summer from Wanli and $46.2 \%(\mathrm{pH}>5)$ in autumn. To further evaluate the precipitation properties in the sampling area, the volume weighted mean (VWM) was performed in this study, and then compared with other 10 regions in East Asia (Table 1). The $\mathrm{pH}$ values of the 10 East Asia regions were between 4.69 and 6.14, with a mean $\mathrm{pH}$ value equal 5.31, Japan, Korea, Malaysia, and Indonesia with $\mathrm{pH}$ values less than 5 . The mean $\mathrm{pH}$ value of this studied areas were lower than the mean of the 10 regions in East Asia. This result may be caused by high concentration of $\mathrm{SO}_{4}{ }^{2-}$ and $\mathrm{NO}_{3}{ }^{-}$and low concentration of neutralizing cations (such as $\mathrm{Ca}^{2+}, \mathrm{Mg}^{2+}$, and $\mathrm{NH}_{4}{ }^{+}$). According to other literature indicated that water in equilibrium with an non-polluted atmosphere containing $\mathrm{CO}_{2}, \mathrm{NO}_{\mathrm{x}}$, and $\mathrm{SO}_{2}$ is slightly acidic and has around $\mathrm{pH}$ value of 5.6 [27-29]. Therefore, precipitation with a $\mathrm{pH}$ lower than this value is often considered as acidic, and this is mainly caused by the anthropogenic emission of $\mathrm{SO}_{2}$ and $\mathrm{NO}_{2}$, originating from industrial activities, coal burning [28].

In this study, the VWM concentration of the ions in Wanli were in order of $\mathrm{Cl}^{-}>\mathrm{Na}^{+}>\mathrm{Mg}^{2+}>$ $\mathrm{SO}_{4}{ }^{2-}>\mathrm{H}^{+}>\mathrm{Ca}^{2+}>\mathrm{NO}_{3}{ }^{-}>\mathrm{NH}_{4}{ }^{+}>\mathrm{K}^{+}$. This was mainly because Wanli is close to the ocean, and the marine derived ion $\left(\mathrm{Cl}^{-}\right.$and $\left.\mathrm{Na}^{+}\right)$concentrations were relatively higher. The VWM concentration of the ions in Banqiao followed the $\mathrm{SO}_{4}{ }^{2-}>\mathrm{NO}_{3}{ }^{-}>\mathrm{Cl}^{-}>\mathrm{NH}_{4}{ }^{+}>\mathrm{Na}^{+}>\mathrm{H}^{+}>\mathrm{Ca}^{2+}>\mathrm{Mg}^{2+}>\mathrm{K}^{+}$downward order. This possibly has been caused by a higher level of anthropogenic activities, which resulted in a higher concentration of anthropogenic ions $\left(\mathrm{SO}_{4}{ }^{2-}\right.$ and $\left.\mathrm{NO}_{3}{ }^{-}\right)$. Al-Momani et al. [30,31] reported that the equivalence ratio of total anions to cations $\left(\Sigma \mathrm{TZ}^{-} / \Sigma \mathrm{TZ}^{+}\right)$indicates the consistency of data quality and measurement parameters. Calculating the total equivalent concentration ratio of negative and positive ions in the rainwater can confirm the reliability of data. Figure 2 presents the linear regression graph, in which $\Sigma \mathrm{TZ}^{-}$is regressed on $\Sigma \mathrm{TZ}^{+}$. The $\Sigma \mathrm{TZ}^{-} / \Sigma \mathrm{TZ}^{+}$ratios for Wanli and Banqiao were 0.812 and 0.880 , respectively, and the regression coefficient was 0.993 and 0.974 , respectively. The total electrical charge ratios for the cations and anions of this study were within the range of $1 \pm 0.25$, which indicated a balanced electrical charge. 
Table 1. The concentrations of major parameters in rainwater at this study and other places in the Asia (units are in $\mu$ eq $\mathrm{L}^{-1} \mathrm{except} \mathrm{pH}$ and rainfall in mm).

\begin{tabular}{|c|c|c|c|c|c|c|c|c|c|c|c|c|c|c|c|}
\hline Locations & & Sampling Period & $\mathrm{SO}_{4}{ }^{2-}$ & nss-SO ${ }_{4}{ }^{2-}$ & $\mathrm{NO}_{3}^{-}$ & $\mathrm{Cl}^{-}$ & $\mathrm{NH}_{4}{ }^{+}$ & $\mathrm{Na}^{+}$ & $\mathrm{K}^{+}$ & $\mathrm{Ca}^{2+}$ & nss-Ca ${ }^{2-}$ & $\mathrm{Mg}^{2+}$ & $\mathrm{H}^{+}$ & $\mathrm{pH}$ & Rainfall \\
\hline Primorskaya, Russia & Rural & 2015 & 42.77 & 39.78 & 25.41 & 25.45 & 25.73 & 24.79 & 7.79 & 26.21 & 25.14 & 11.23 & 6.90 & 5.16 & 1157 \\
\hline Tokyo, Japan & Urban & 2015 & 23.41 & 21.24 & 16.27 & 22.16 & 20.13 & 18.04 & 0.64 & 7.12 & 6.34 & 4.90 & 16.35 & 4.79 & 1641 \\
\hline Kanghwa, Korea & Rural & 2015 & 58.78 & 53.35 & 50.46 & 161.32 & 99.02 & 45.02 & 106.41 & 19.04 & 17.11 & 7.21 & 20.21 & 4.69 & 589 \\
\hline Xiaoping, China & Urban & 2015 & 100.56 & 100.12 & 47.42 & 7.78 & 95.15 & 3.61 & 5.99 & 86.06 & 85.91 & 9.59 & 3.81 & 5.42 & 1557 \\
\hline Mt. Sto. Tomas, Philippines & Rural & 2015 & 8.04 & 6.99 & 3.49 & 7.79 & 9.57 & 8.71 & 1.63 & 13.69 & 13.32 & 6.89 & 1.10 & 5.96 & 6108 \\
\hline Bangkok, Thailand & Urban & 2015 & 15.05 & 14.09 & 16.16 & 7.36 & 60.74 & 7.97 & 1.75 & 33.89 & 33.55 & 3.79 & 5.09 & 5.29 & 1593 \\
\hline Ho Chi Minh, Vietnam & Urban & 2015 & 95.19 & 91.02 & 17.97 & 52.03 & 29.44 & 34.57 & 12.02 & 88.51 & 87.02 & 35.79 & 0.78 & 6.11 & 1420 \\
\hline Phnom Penh, Combodia & Urban & 2015 & 14.08 & 13.33 & 10.36 & 9.01 & 18.06 & 6.28 & 1.98 & 23.20 & 22.93 & 5.11 & 0.72 & 6.14 & 1103 \\
\hline Tanah Rata, Malaysia & Rural & 2015 & 13.72 & 13.39 & 7.63 & 3.75 & 7.54 & 2.74 & 2.37 & 3.99 & 3.89 & $>0.6$ & 19.14 & 4.72 & 2684 \\
\hline $\begin{array}{l}\text { Jakarta, Indonesia } \\
\text { This Study }\end{array}$ & Urban & 2015 & 34.21 & 32.54 & 15.27 & 17.10 & 18.94 & 2.01 & 12.54 & 14.94 & 14.85 & 3.61 & 14.44 & 4.84 & 2807 \\
\hline$\overline{\text { Wanli, Taiwan }}$ & Costal & $11 / 2014-10 / 2015$ & 69.42 & 52.00 & 25.96 & 171.79 & 23.89 & 144.72 & 8.35 & 38.61 & 32.30 & 73.26 & 46.51 & 4.63 & 6790 \\
\hline Banqiao, Taiwan & Urban & $11 / 2014-10 / 2015$ & 44.01 & 40.44 & 34.98 & 33.65 & 31.37 & 29.68 & 2.99 & 25.76 & 24.46 & 12.83 & 28.63 & 4.58 & 3873 \\
\hline
\end{tabular}

The data of other places is from Acid Deposition Monitoring in East Asia https://monitoring.eanet.asia/document/public/index. 


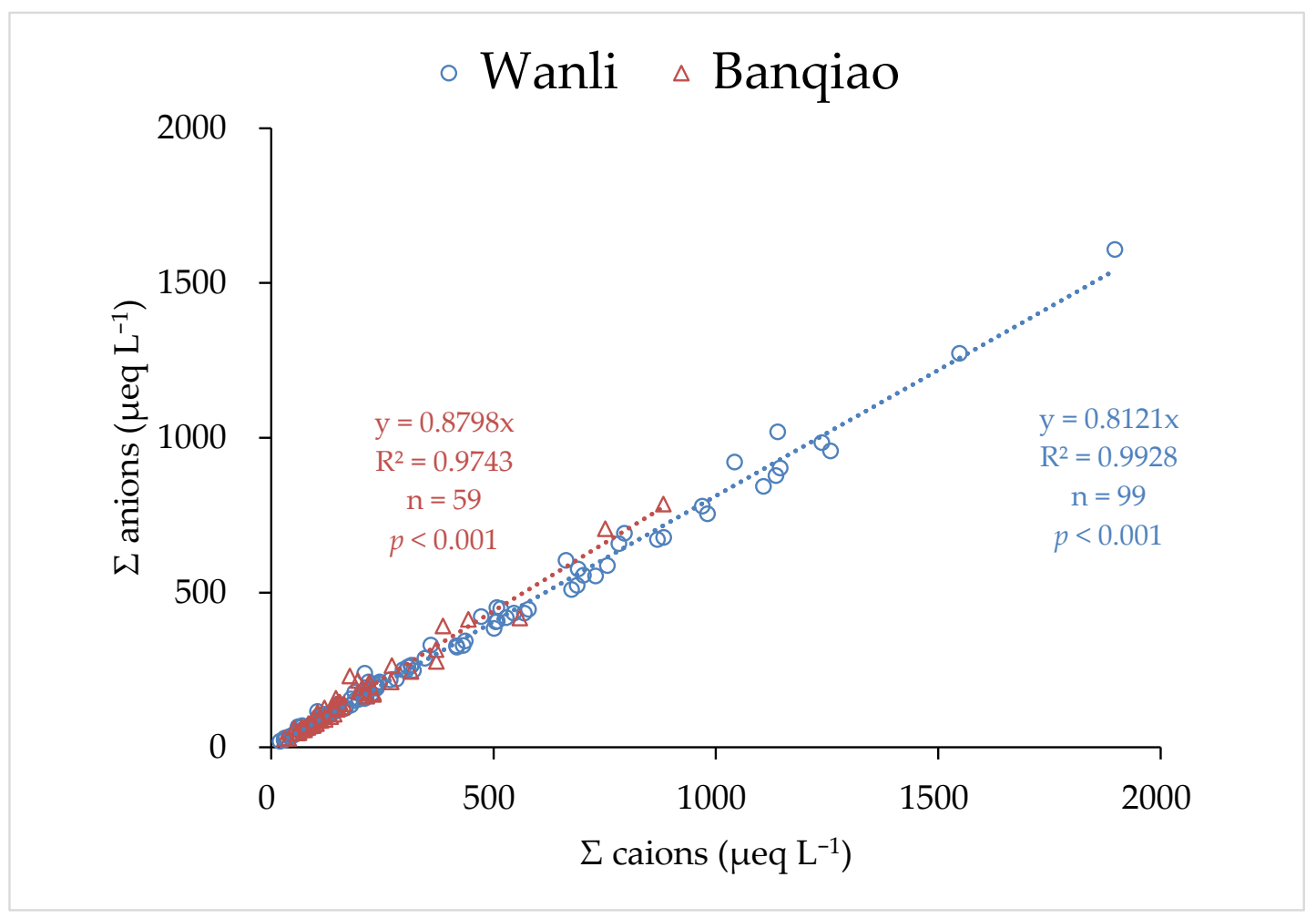

Figure 2. Relationship between the sum of cations and anions $\left(\mu \mathrm{eq} \mathrm{L}^{-1}\right)$.

Figure 3 illustrates the spatial changes in the chemical components of wet deposition in the 10 East Asian regions and this study. In this figure, the main ion concentration of each region is displayed as colored lines on the linear scale. Almost all of $\mathrm{SO}_{4}{ }^{2-}, \mathrm{Ca}^{2+}$, and $\mathrm{NH}_{4}{ }^{+}$in this areas were as the main ions in wet deposition, which is that these areas were clearly affected by human activities. This was mainly because Wanli had the highest sea salt ion concentration of $\mathrm{Cl}^{-}(171.79 \mu \mathrm{eq} \mathrm{L}-1), \mathrm{Na}^{+}(144.72 \mu \mathrm{eq} \mathrm{L}-1)$, and $\mathrm{Mg}^{2+}\left(73.26 \mu \mathrm{eq} \mathrm{L}{ }^{-1}\right)$, more than 5 times the means of the 10 East Asia regions $\left(\mathrm{Cl}^{-}: 31.37 \mu \mathrm{eq} \mathrm{L}{ }^{-1}\right.$, $\mathrm{Na}^{+}: 15.37 \mu \mathrm{eq} \mathrm{L}{ }^{-1}$, and $\left.\mathrm{Mg}^{2+}: 8.87 \mu \mathrm{eq} \mathrm{L}{ }^{-1}\right)$. The acid ion concentrations of $\mathrm{SO}_{4}{ }^{2-}\left(69.42 \mu \mathrm{eq} \mathrm{L}{ }^{-1}\right)$ and $\mathrm{NO}_{3}{ }^{-}\left(25.96 \mu \mathrm{eq} \mathrm{L}{ }^{-1}\right)$ in Wanli were higher than the mean of the 10 East Asia regions $\left(\mathrm{SO}_{4}{ }^{2-}\right.$ : $40.58 \mu \mathrm{eq} \mathrm{L} \mathrm{L}^{-1}$ and $\left.\mathrm{NO}_{3}^{-}: 21.04 \mu \mathrm{eq} \mathrm{L}{ }^{-1}\right)$. In Banqiao, the concentrations of $\mathrm{SO}_{4}{ }^{2-}\left(44.01 \mu \mathrm{eq} \mathrm{L}{ }^{-1}\right)$ and $\mathrm{NO}_{3}^{-}\left(34.98 \mu \mathrm{eq} \mathrm{L}{ }^{-1}\right)$ were higher than the means of the 10 East Asian regions, but the $\mathrm{NH}_{4}^{+}$ concentration $\left(31.37 \mu \mathrm{eq} \mathrm{L}{ }^{-1}\right)$ was lower than the mean of the 10 East Asia regions $(38.43 \mu \mathrm{eq} \mathrm{L}-1)$. In general, $\mathrm{Cl}^{-}, \mathrm{Na}^{+}$, and $\mathrm{Mg}^{2+}$ are classified as sea-derived ions [9]. The sum of sea-salt ions $\left(\mathrm{Cl}^{-}\right.$, $\mathrm{Na}^{+}$, and $\mathrm{Mg}^{2+}$ ) in wet deposition of Wanli and Banqiao accounted for $64.7 \%$ and $31.2 \%$ of the total ion concentration, respectively (Figure 4 ). The sum of the acidic ions $\left(\mathrm{SO}_{4}{ }^{2-}\right.$ and $\left.\mathrm{NO}_{3}{ }^{-}\right)$in wet deposition of Wanli and Banqiao accounted for 15.8\% and 32.4\%, respectively. For wet deposition of the 10 East Asian regions, the average percentage of sea-salt ions and acidic ions in the total ion concentration were $26.3 \%$ and $29.1 \%$, respectively. This clearly differed from the ion composition in wet deposition from northern Taiwan. Furthermore, the ion composition of the two sampling stations in this study was significantly different. The higher concentration of sea-salt ions represents the characteristics of the coastal area of Wanli. As mentioned in 2.1, Banqiao is a typical urban area with a high degree of commercial and industrial development, mainly manifested by high emissions of $\mathrm{SO}_{2}, \mathrm{NO}_{x}$, and $\mathrm{NH}_{3}$. Regarding the concentration of main acidic ions in the total ion concentration, Banqiao was double that of Wanli, which may have contributed to wet deposition of Banqiao pH being lower than that of Wanli. 


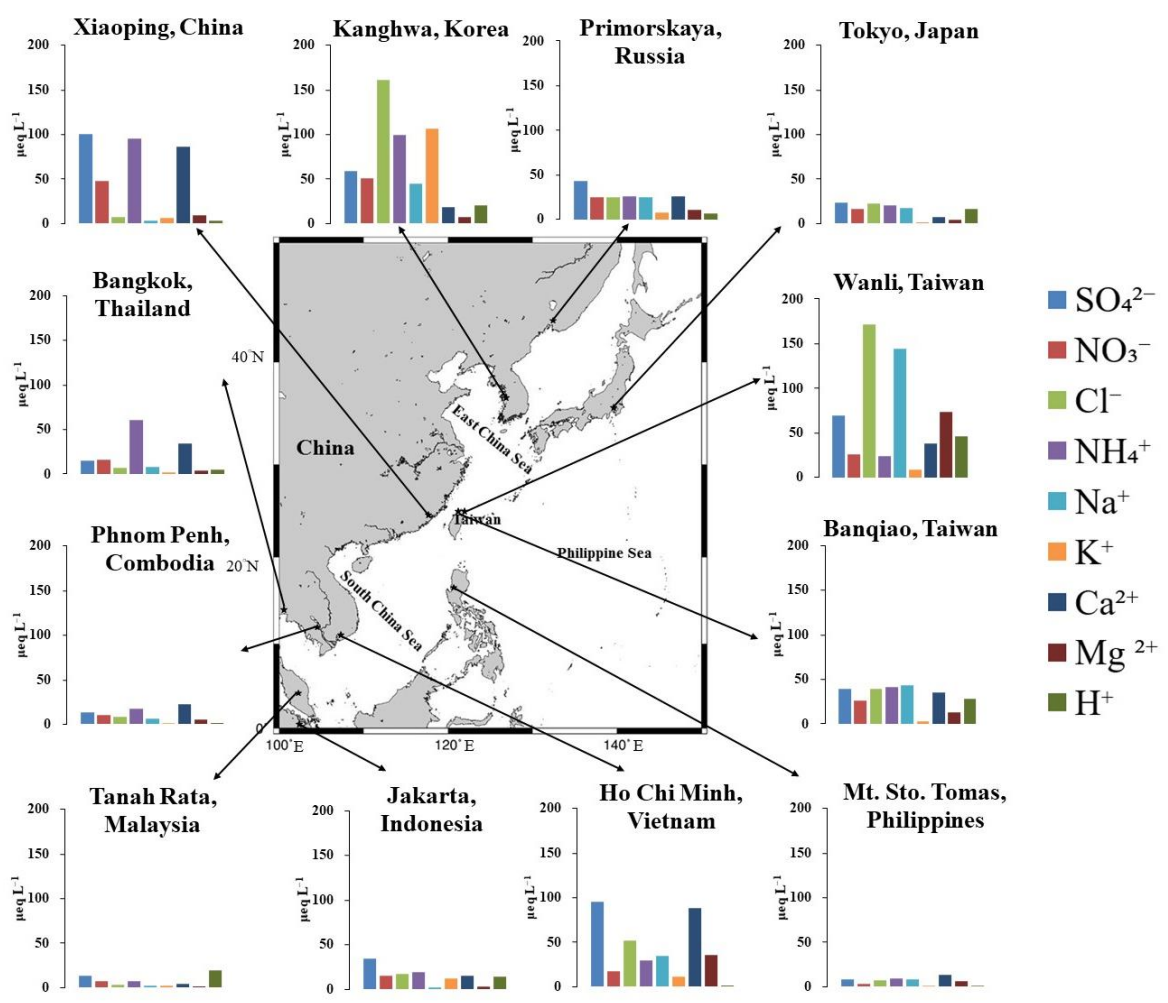

Figure 3. Volume weighted means of major ions in precipitation around East Asia.

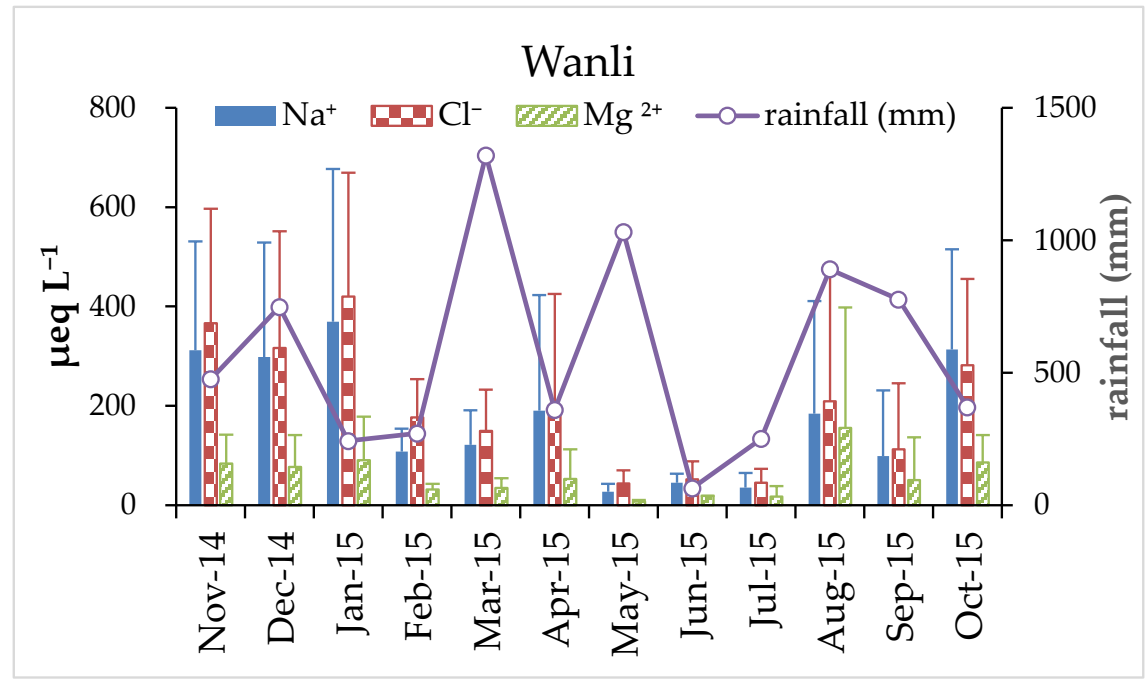

Figure 4. Cont. 


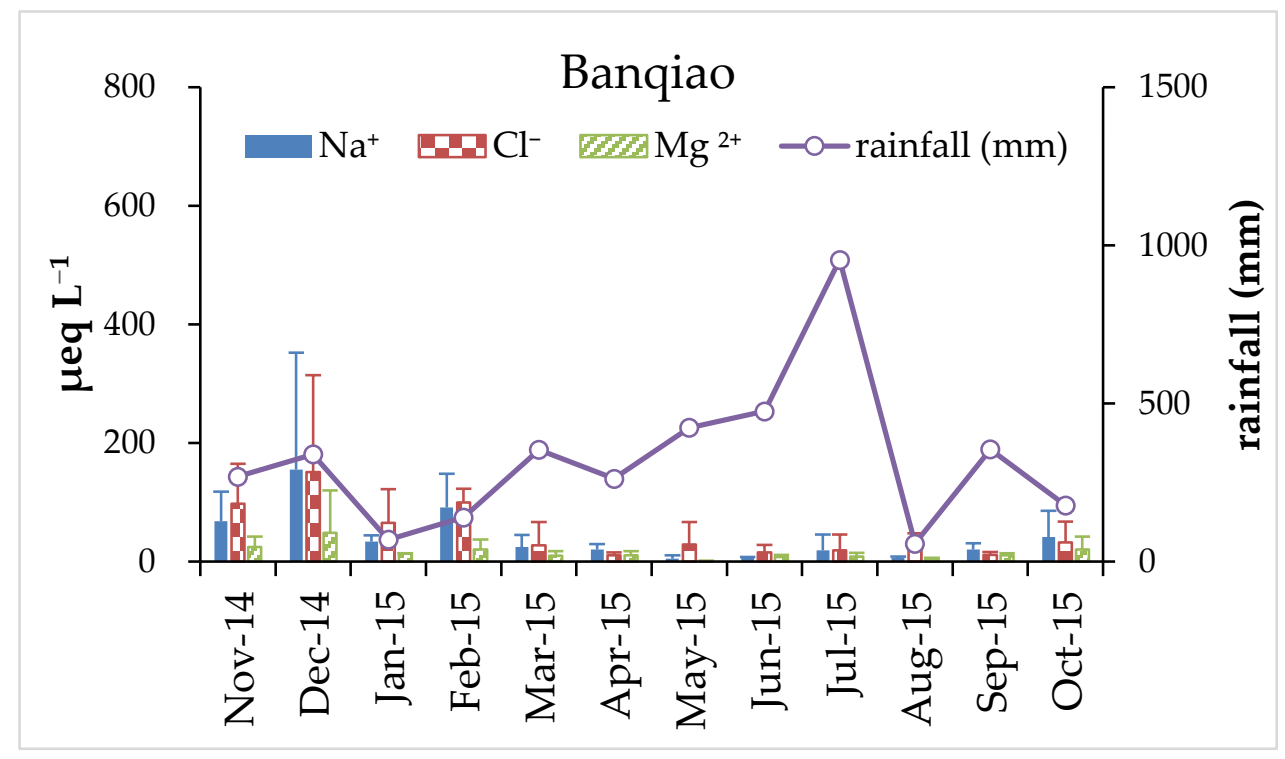

Figure 4. Variations in the monthly average concentrations of sea-salt ions at Wanli and Banqiao. (error bars represent the standard deviations for each month).

\subsection{Enrichment Factors and Relative Source Contributions}

The chemical composition of precipitation was mainly affected by anthropogenic sources, sea spray, volcanic activity, biological matter, and wind-blown dust from weathering minerals $[18,32,33]$. Thus, the ratio between ion and the index ions (enrichment factor; EF) could be used to find out the derived source of the ions. The EFs are often calculated to identify the derived source and contributions of major ions in rainwater $[34,35]$. Generally, $\mathrm{Na}^{+}$is used as the indicator element of seawater, since it is assumed to be originating only from marine sources [3,36], and $\mathrm{Ca}^{2+}$ is as a reference ion for the crustal indicator [19]. Table 2 presents the ratio of $\mathrm{EF}_{\mathrm{m}}$ to $\mathrm{EF}_{\mathrm{c}}$. If the $\mathrm{EF}$ value is significantly larger or smaller than 1 , the element's corresponding reference source was enriched or diluted, respectively $[18,37,38]$.

Table 2. Enrichment factors for sea salt and crust components relative for rainwater.

\begin{tabular}{|c|c|c|c|c|c|c|c|c|c|c|}
\hline & \multicolumn{5}{|c|}{$\mathrm{EF}_{\mathrm{m}}$} & \multicolumn{5}{|c|}{$\mathbf{E F}_{\mathrm{c}}$} \\
\hline & $\mathrm{Cl}^{-}$ & $\mathrm{K}^{+}$ & $\mathrm{Ca}^{2+}$ & $\mathrm{Mg}^{2+}$ & $\mathrm{SO}_{4}{ }^{2-}$ & $-\mathrm{Cl}^{-}$ & $\mathrm{K}^{+}$ & $\mathrm{Na}^{+}$ & $\mathrm{Mg}^{2+}$ & $\mathrm{SO}_{4}^{2-}$ \\
\hline Primorskaya, Russia & 0.88 & 14.28 & 24.03 & 2.00 & 14.26 & $>100$ & 0.59 & 1.66 & 0.76 & 85.88 \\
\hline Tokyo, Japan & 1.06 & 1.62 & 8.97 & 1.20 & 10.73 & $>100$ & 0.18 & 4.45 & 1.23 & $>100$ \\
\hline Kanghwa, Korea & 3.09 & $>100$ & 9.61 & 0.71 & 10.79 & $>100$ & 11.09 & 4.16 & 0.68 & $>100$ \\
\hline Xiaoping, China & 1.86 & 75.43 & $>100$ & 11.70 & $>100$ & 30.12 & 0.14 & 0.07 & 0.20 & 61.50 \\
\hline $\begin{array}{l}\text { Mt. Sto. Tomas, } \\
\text { Philippines }\end{array}$ & 0.77 & 8.48 & 35.73 & 3.48 & 7.63 & $>100$ & 0.24 & 1.12 & 0.90 & 30.90 \\
\hline Bangkok, Thailand & 0.80 & 9.97 & 96.61 & 2.09 & 1.89 & 72.39 & 0.10 & 0.41 & 0.20 & 23.37 \\
\hline Ho Chi Minh, Vietnam & 1.30 & 15.80 & 58.19 & 4.56 & 22.76 & $>100$ & 0.27 & 0.69 & 0.72 & 56.60 \\
\hline Phnom Penh, Combodia & 1.24 & 14.35 & 84.00 & 3.59 & 18.54 & $>100$ & 0.17 & 0.48 & 0.39 & 31.95 \\
\hline Tanah Rata, Malaysia & 1.18 & 39.25 & 33.10 & 0.96 & 41.34 & $>100$ & 1.18 & 1.21 & 0.27 & $>100$ \\
\hline $\begin{array}{c}\text { Jakarta, Indonesia } \\
\text { This Study }\end{array}$ & 7.32 & $>100$ & $>100$ & 7.90 & $>100$ & $>100$ & 1.67 & 0.24 & 0.43 & $>100$ \\
\hline Wanli, Taiwan & 1.02 & 2.62 & 6.06 & 2.23 & 3.96 & $>100$ & 0.43 & 6.59 & 0.90 & 94.63 \\
\hline Banqiao, Taiwan & 0.98 & 4.57 & 19.73 & 1.90 & 12.26 & $>100$ & 0.23 & 2.02 & 0.77 & 89.92 \\
\hline
\end{tabular}

(EF) calculation was based on Equations (6) and (7), $\mathrm{Na}^{+}$is used as a sea source reference, $\mathrm{Ca}^{2+}$ is used as crust source reference $[3,14]$.

The $\mathrm{EF}_{\mathrm{m}}$ of $\mathrm{Cl}^{-}$for Wanli and Banqiao was 1.02 and 0.98 , respectively, and the $\mathrm{EF}_{\mathrm{c}}$ values were greater than 100 for both stations. These results indicated that $\mathrm{Cl}^{-}$mainly derived from marine source. The $\mathrm{EF}_{\mathrm{m}}$ of $\mathrm{K}^{+}$(2.62 for Wanli and 4.57 for Banqiao) was greater than 1, which indicated that it may 
have been derived from other sources. The $\mathrm{EF}_{\mathrm{C}}$ of $\mathrm{K}^{+}(0.43$ for Wanli and 0.23 for Banqiao) was lower than 1 may have been diluted by other sources. Suspended particles of $\mathrm{K}^{+}$were the result of biomass combustion [32] and can be found in certain chemical fertilizers [39]. The calculation results of $\mathrm{EF}_{\mathrm{m}}$ (2.23 for Wanli and 1.90 for Banqiao) and $\mathrm{EF}_{\mathrm{C}}$ ( 0.90 for Wanli and 0.77 for Banqiao) of $\mathrm{Mg}^{2+}$ were similar to those of $\mathrm{K}^{+}$. The source may have been crustal, with a part from other sources. The $\mathrm{EF}_{\mathrm{m}} \mathrm{of} \mathrm{Ca}^{2+}$ (6.06 for Wanli and 19.73 for Banqiao) indicated that it did not come from marine sources and may have been derived from the soil, land dust or limestone, or the weathering of dolomite [38]. The $\mathrm{EF}_{\mathrm{m}}$ (3.96 for Wanli and 12.3 for Banqiao) and $\mathrm{EF}_{\mathrm{C}}$ (94.6 for Wanli and 89.9 for Banqiao) of $\mathrm{SO}_{4}{ }^{2-}$ existed in a highly enriched form. This suggested that anthropogenic activities had a significant effect and that soil dust and sea-salts had the least contribution [18,19].

In order to estimate the contribution of marine and non-marine species in wet deposition, this study used $\mathrm{Na}^{+}$as the reference element [40] to calculate the SSF and non-SSF (NSSF). The NSSF was further divided into CF and AF. For the wet deposition in this study (Table 3), the SSF of $\mathrm{Cl}^{-}$reached up to $97.72 \%$, and the ratio of $\mathrm{Na}^{+}$was also as high as $90 \%$. Therefore, $\mathrm{Na}^{+}$and $\mathrm{Cl}^{-}$in northern Taiwan mainly came from marine sources. For NSSF, crustal $\mathrm{Ca}^{2+}$ and $\mathrm{K}^{+}$in wet deposition was also up to $61.88 \%$ to showing from crustal sources, whereas anthropogenic $\mathrm{SO}_{4}{ }^{2-}$ and $\mathrm{NO}_{3}{ }^{-}$were over $73.72 \%$, especially in Banqiao to express clearly that $\mathrm{SO}_{4}{ }^{2-}$ and $\mathrm{NO}_{3}{ }^{-}$came from anthropogenic sources. For wet deposition in Banqiao, $94.93 \%$ of $\mathrm{Ca}^{2+}$ and $78.14 \%$ of $\mathrm{K}^{+}$came from crustal sources, whereas $90.73 \%$ and $99.85 \%$ of $\mathrm{SO}_{4}{ }^{2-}$ and $\mathrm{NO}_{3}{ }^{-}$, respectively, came from anthropogenic sources.

Table 3. Contributions of the source for major ions.

\begin{tabular}{ccccccc}
\hline & \multicolumn{3}{c}{ Wanli } & \multicolumn{3}{c}{ Banqiao } \\
\cline { 2 - 7 } & Marine & Crust & Anthorpogenic & Marine & Crust & Anthorpogenic \\
\cline { 2 - 7 } & $\mathbf{S S F}(\%)$ & $\mathbf{C F}(\%)$ & $\mathbf{A F}(\%)$ & $\mathbf{S S F}(\%)$ & $\mathbf{C F}(\%)$ & AF(\%) \\
\hline $\mathrm{Na}^{+}$ & 84.82 & 15.18 & & 50.61 & 49.39 & \\
$\mathrm{Ca}^{2+}$ & 16.49 & 83.51 & & 5.07 & 94.93 & \\
$\mathrm{Mg}^{2+}$ & 44.84 & 29.57 & 25.59 & 52.50 & 47.50 & \\
$\mathrm{~K}^{+}$ & 38.12 & 61.88 & & 21.86 & 78.14 & \\
$\mathrm{Cl}^{-}$ & 97.72 & 0.07 & 2.21 & 99.77 & 0.23 & \\
$\mathrm{SO}_{4}{ }^{2-}$ & 25.22 & 1.06 & 73.72 & 8.16 & 1.11 & 90.73 \\
$\mathrm{NO}_{3}{ }^{-}$ & & 0.30 & 99.70 & & 0.15 & 99.85 \\
\hline
\end{tabular}

Figure 5 shows the temporal changes and monsoon characteristics of nss-SO ${ }_{4}^{2-}$ and nss-Ca ${ }^{2+}$ from the two sampling stations. Wanli's low concentration happened during the period from May to July, whereas that of Banqiao occurred during the period from May to September. As mentioned in 2.1, the high percentage of nss- $\mathrm{SO}_{4}{ }^{2-}$ indicated the effect of rapid industrialization, which was accompanied by high degree of energy consumption and $\mathrm{SO}_{2}$ emission [37]. The results in all these studied areas revealed that $\mathrm{Ca}^{2+}$ in wet deposition may have come from crust. Almost all of $\mathrm{Ca}^{2+}$ cannot only be attributed to crustal sources, namely rocks (dolomite and limestone) weathering $[33,36]$. Large quantities of nss- $\mathrm{Ca}^{2+}$ may have been derived from the distant transportation of soil and dust from arid and semiarid areas [37]; however, $\mathrm{nss}^{-\mathrm{Ca}^{2+}}$ can also be attributed to anthropogenic activities, such as that from quarries or cement plants [41]. 

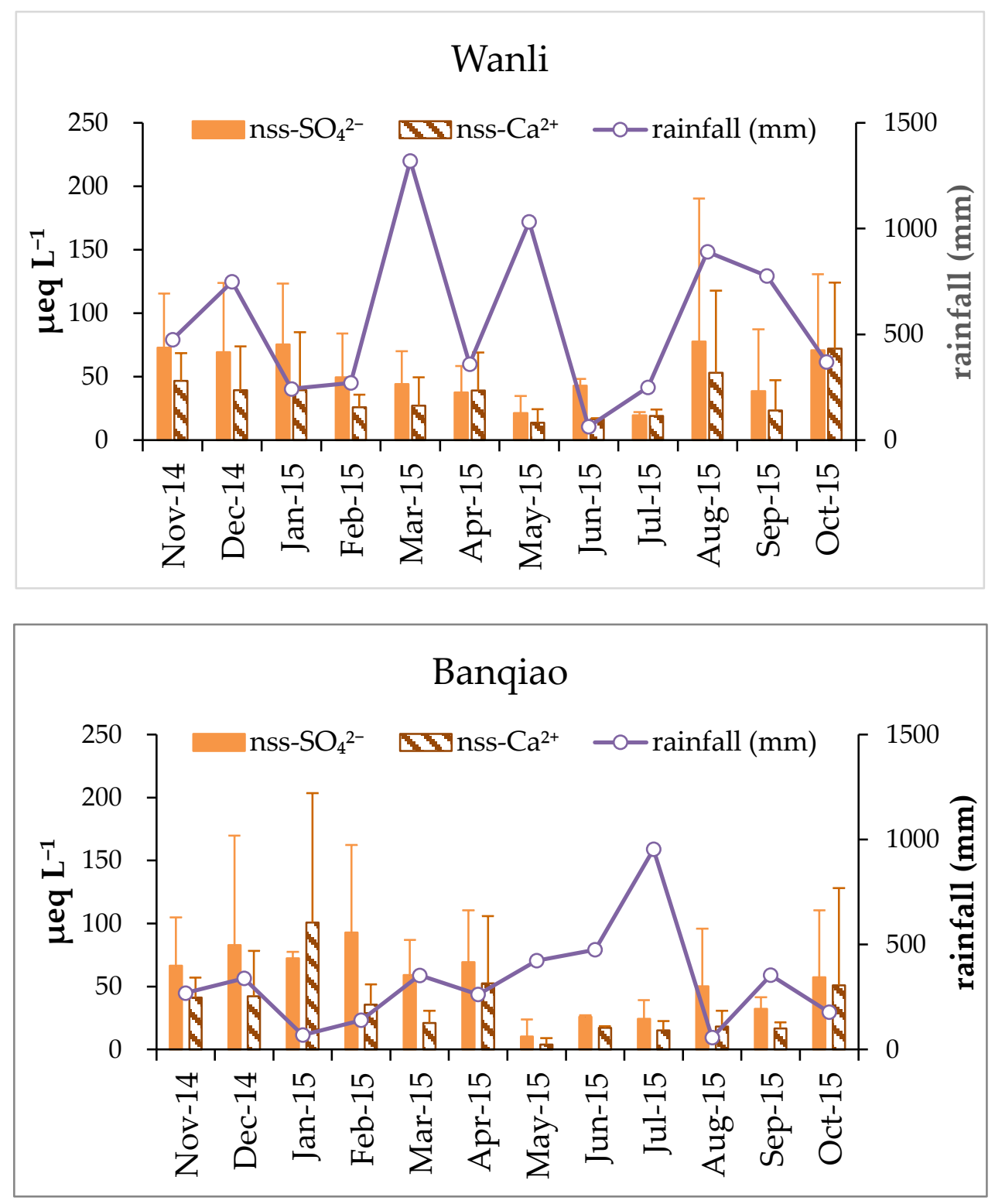

Figure 5. Variations in the monthly average concentrations of non-sea-salt ions at Wanli and Banqiao. (error bars represent the standard deviations for each month).

\subsection{Neutralization and Alkalization of Rainwater}

Generally, the acidity of wet deposition is controlled by acidic ions dissociation from $\mathrm{H}_{2} \mathrm{SO}_{4}$ and $\mathrm{HNO}_{3}$. The neutralization of these acidic substances mainly occurs from the presence of $\mathrm{NH}_{3}$ and $\mathrm{CaCO}_{3}[27,37]$. Harrison and Pio (1983) [42] indicated that $\mathrm{SO}_{4}{ }^{2-}$ and $\mathrm{NO}_{3}{ }^{-}$ion concentrations remain relatively constant with elevation and that $\mathrm{NH}_{3}$ and $\mathrm{NH}_{4}{ }^{+}$ion concentrations rapidly decrease with increasing elevation. According to the above, at cloud level acidic species such as $\mathrm{H}_{2} \mathrm{SO}_{4}$, $\mathrm{HNO}_{3}$, and $\mathrm{NH}_{4} \mathrm{HSO}_{4}$ are more likely to be in majority over neutralized species like $\left(\mathrm{NH}_{4}\right)_{2} \mathrm{SO}_{4}$ and $\mathrm{NH}_{4} \mathrm{NO}_{3}$ [20]. Neutralization process occurs when $\mathrm{Ca}(\mathrm{OH})_{2}$ and $\mathrm{Mg}(\mathrm{OH})_{2}$ reacts with $\mathrm{H}_{2} \mathrm{SO}_{4}$ and $\mathrm{HNO}_{3}$ in cloud condensation nuclei. Below the clouds, $\mathrm{SO}_{2}$ adsorbs suspended particulates that contain $\mathrm{Ca}^{2+}$ and $\mathrm{Mg}^{2+}$ and then reacts with ammonia to produce neutralization $[20,43]$. In wet deposition, nss- $\mathrm{SO}_{4}{ }^{2-}$ and $\mathrm{NO}_{3}{ }^{-}$are the two main acidic components. Therefore, FA can be used to evaluate the neutralization level of wet deposition acidity $[20,38]$.

In the study area, the FA (Table 4) was 0.60 for Wanli and 0.38 for Banqiao. This suggested that $40 \%$ and $62 \%$ of inorganic acids were neutralized within wet deposition of Wanli and Banqiao, 
respectively. The mean FA of the 10 nearby regions was 0.23 , which varied between 0.01 and 0.91 . This indicated that about $77 \%$ of acidic substances were neutralized in the East Asia. For the NF, $\mathrm{Mg}^{2+}(0.70)$ had the highest neutralizing capability in Wanli, followed by $\mathrm{Ca}^{2+}(0.37)$ and $\mathrm{NH}_{4}{ }^{+}(0.18)$. In Banqiao, $\mathrm{NH}_{4}{ }^{+}(0.27)$ and $\mathrm{Ca}^{2+}(0.23)$ had the strongest neutralizing capability, followed by $\mathrm{Mg}^{2+}$ (0.12). To understand the acidification reaction of wet deposition, the NP and AP ratios were used to determine the neutralizing and acidifying characteristics, respectively, of wet deposition. AP is the sum of nss- $\mathrm{SO}_{4}{ }^{2-}$ and $\mathrm{NO}_{3}{ }^{-}$, and $\mathrm{NP}$ is the sum of nns-Ca ${ }^{2+}$ and $\mathrm{NH}_{4}{ }^{+}[44,45]$. The NP/AP value in the study area was less than 1 ( 0.72 for Wanli and 0.74 for Banqiao). Although the neutralization of precipitation acidity occurred, the precipitation NP was less than the AP. Thus, acidic ions exceeded neutralizing ions, and wet deposition exhibited acidic characteristics.

Table 4. Neutralization Factor analysis result.

\begin{tabular}{ccccccc}
\hline \multirow{2}{*}{ FA } & \multicolumn{2}{c}{$\left.\mathbf{N F}_{(\mathbf{X}}{ }^{+}\right)$} & \multicolumn{2}{c}{$\mathbf{N F}_{\left(\mathbf{X}^{2+}\right)}$} & \multirow{2}{*}{$\mathbf{N P / A P}$} \\
\cline { 3 - 5 } & & $\mathbf{N H}_{4}{ }^{+}$ & $\mathbf{K}^{+}$ & $\mathbf{M g}^{2+}$ & $\mathbf{C a}^{2+}$ & \\
\hline Wanli & 0.60 & 0.18 & 0.06 & 0.70 & 0.37 & 0.72 \\
Banqiao & 0.38 & 0.27 & 0.03 & 0.12 & 0.23 & 0.74 \\
\hline
\end{tabular}

The mean concentration of $\mathrm{NH}_{4}{ }^{+}$in wet deposition of Wanli and Banqiao was 23.89 and $31.37 \mu \mathrm{eq} \mathrm{L} \mathrm{L}^{-1}$, respectively, which was lower than the mean of the 10 East Asian regions $\left(38.43 \mu \mathrm{eq} \mathrm{L} \mathrm{L}^{-1}\right)$. The mean AAI of the 10 East Asia regions was 69.45\%, which was higher than that of Wanli (25.05\%) and Banqiao (39.72\%). This indicated that northern Taiwan had insufficient ammonia to neutralize the sulfuric acid and nitric acid. The $\mathrm{NH}_{4}{ }^{+} / \mathrm{NO}_{3}{ }^{-}$ratio (Figure 6) for Wanli (0.92) and Banqiao (0.90) was less than 1. This indicated that ammonia contributed little to the neutralization of precipitation acidity. However, the $\mathrm{NH}_{4}{ }^{+} / \mathrm{NO}_{3}{ }^{-}$mean for the 10 East Asian regions was 1.83, which was significantly higher than 1.00. Thus, ammonia neutralized the nitrates to form $\mathrm{NH}_{4} \mathrm{NO}_{3}$ in the atmosphere [46].

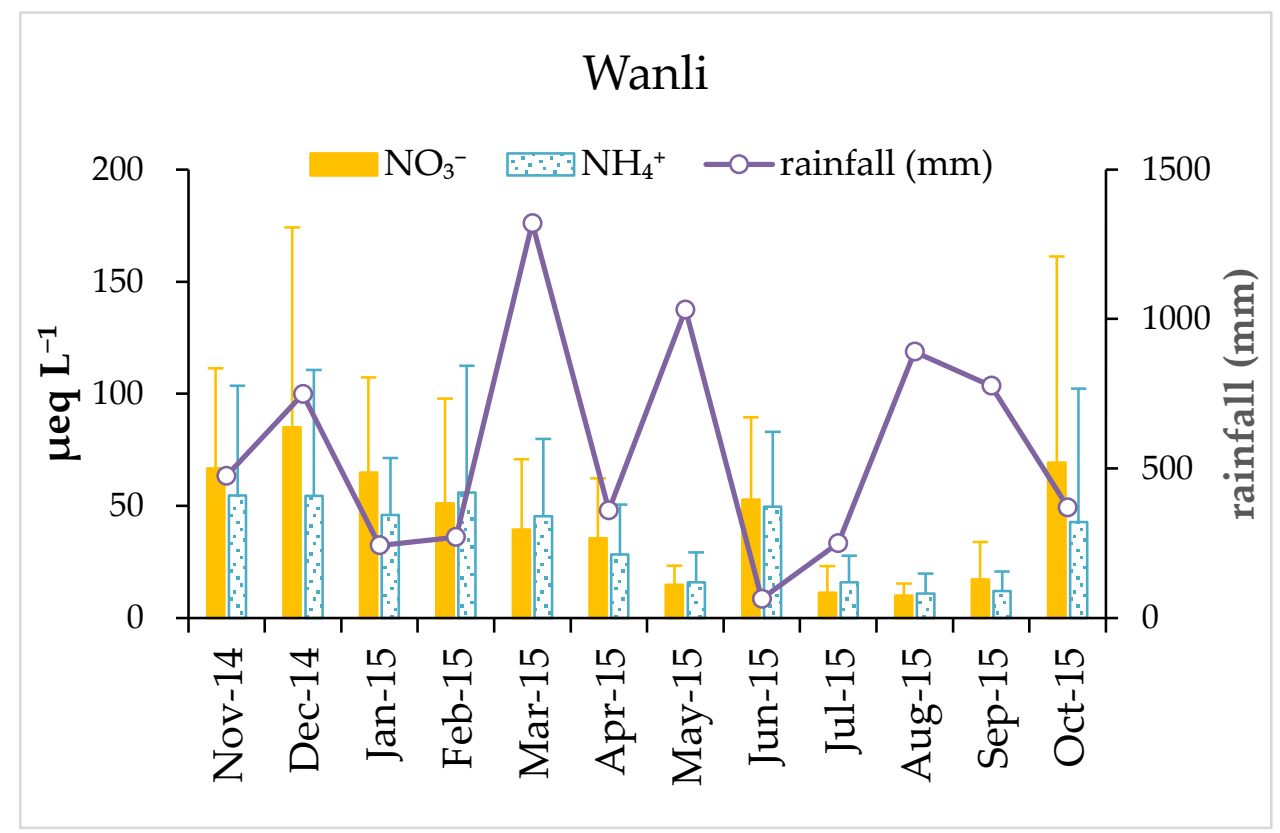

Figure 6. Cont. 


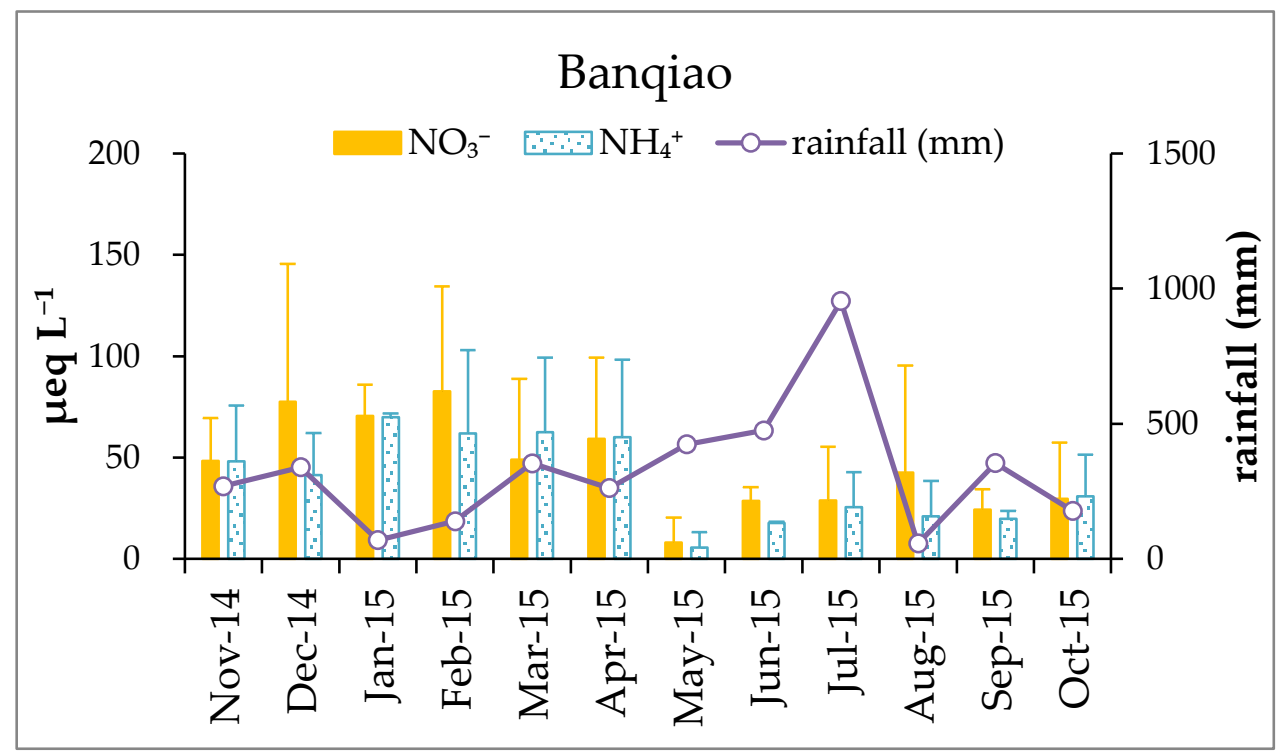

Figure 6. Variations in the monthly average concentrations of $\mathrm{NO}_{3}{ }^{-}$and $\mathrm{NH}_{4}{ }^{+}$at Wanli and Banqiao. (error bars represent the standard deviations for each month).

\subsection{Correlation Analysis and PCA}

The correlation analysis of the main ions in the study region (Table 5) presents a significant and positive correlation between $\mathrm{Na}^{+}$and $\mathrm{Cl}^{-}$for the two monitoring stations ( 0.994 for Wanli and 0.907 for Banqiao). This indicated that the $\mathrm{Na}^{+}$and $\mathrm{Cl}^{-}$mainly came from marine sources [38], and a high degree of correlation occurred between $\mathrm{Mg}^{2+}, \mathrm{Ca}^{2+}$, and $\mathrm{SO}_{4}{ }^{2-}$ and sea-salt ions $\mathrm{Na}^{+}$and $\mathrm{Cl}^{-}$at Wanli station $(R>0.953)$. This indicated that the $\mathrm{Mg}^{2+}, \mathrm{Ca}^{2+}$, and $\mathrm{SO}_{4}{ }^{2-}$ from the coastal area may have been derived from marine sources. In wet deposition in Banqiao, a significant correlation occurred between $\mathrm{SO}_{4}{ }^{2-}$ and $\mathrm{NO}_{3}{ }^{-}(R=0.878)$. The precipitation source may have been similar to chemical reactions such as the combustion of fossil fuel or industrial activity [37] and co-emission of their precursors [19]. However, the wet deposition in Wanli did not reveal a high correlation between $\mathrm{SO}_{4}{ }^{2-}$ and $\mathrm{NO}_{3}{ }^{-}$ $(R=0.132)$. This indicated that the sources of acid ions from the two areas were inconsistent. $\mathrm{Mg}^{2+}$ and $\mathrm{Ca}^{2+}$ (0.989 for Wanli and 0.620 for Banqiao) had a good correlation. Studies have indicated that other than natural dust, the high correlation between the two ions may have been caused by quarries or cement plants in urban areas [38,47-49]. A positive correlation $(R>0.629)$ occurred between $\mathrm{Na}^{+}$, $\mathrm{Mg}^{2+}, \mathrm{Ca}^{2+}$, and $\mathrm{NH}_{4}{ }^{+}$and $\mathrm{SO}_{4}{ }^{2-}$ and $\mathrm{NO}_{3}{ }^{-}$for wet deposition in Banqiao. Lu et al. [19] indicated that this may result from the reaction between alkaline substances with rich $\mathrm{Ca}^{2+}$ and $\mathrm{Mg}^{2+}$ content and $\mathrm{H}_{2} \mathrm{SO}_{4}, \mathrm{HNO}_{3}$, and $\mathrm{HCl}$. In the atmosphere, ammonia often occurs in the form of $\left(\mathrm{NH}_{4}\right)_{2} \mathrm{SO}_{4}, \mathrm{NH}_{4} \mathrm{H}$ $\mathrm{SO}_{4}$, and $\mathrm{NH}_{4} \mathrm{NO}_{3}$. These are the product of the reaction between ammonia, $\mathrm{H}_{2} \mathrm{SO}_{4}$, and $\mathrm{HNO}_{3}$ [32]. 
Table 5. Pearson's correlation coefficient for ionic constituents.

\begin{tabular}{|c|c|c|c|c|c|c|c|c|c|c|c|c|c|c|c|}
\hline & & & & \multicolumn{11}{|c|}{ Wanli $\mathrm{n}=99$} & \multirow[b]{2}{*}{$\mathrm{H}^{+}$} \\
\hline & $\mathrm{H}^{+}$ & & & 1 & 0.132 & 0.770 ** & 0.033 & 0.077 & 0.782 ** & -0.031 & -0.065 & -0.023 & 0.022 & -0.037 & \\
\hline $\mathrm{H}^{+}$ & 1 & $\mathrm{CI}^{-}$ & & $\mathrm{H}^{+}$ & 1 & 0.209 * & $0.972 * *$ & $0.994^{* *}$ & 0.126 & $0.679 * *$ & 0.953 ** & $0.968^{* *}$ & $0.959 * *$ & $0.959 * *$ & $\mathrm{CI}^{-}$ \\
\hline $\mathrm{CI}^{-}$ & 0.253 & 1 & $\mathrm{NO}_{3}{ }^{-}$ & & $\mathrm{CI}^{-}$ & 1 & 0.132 & 0.195 & $0.895^{* *}$ & 0.002 & 0.023 & 0.103 & 0.115 & 0.089 & $\mathrm{NO}_{3}{ }^{-}$ \\
\hline $\mathrm{NO}_{3}^{-}$ & $0.637^{* *}$ & $0.457^{* *}$ & 1 & $\mathrm{SO}_{4}{ }^{2-}$ & & $\mathrm{NO}_{3}{ }^{-}$ & 1 & $0.974^{* *}$ & 0.055 & $0.657^{* *}$ & $0.989 * *$ & 0.991 ** & $0.999^{* *}$ & $0.988^{* *}$ & $\mathrm{SO}_{4}{ }^{2-}$ \\
\hline $\mathrm{SO}_{4}{ }^{2-}$ & $0.465^{* *}$ & $0.696^{* *}$ & $0.878^{* *}$ & 1 & $\mathrm{Na}^{+}$ & & $\mathrm{SO}_{4}{ }^{2-}$ & 1 & 0.088 & $0.648^{* *}$ & $0.956^{* *}$ & 0.971 ** & 0.960 ** & $0.962^{* *}$ & $\mathrm{Na}^{+}$ \\
\hline $\mathrm{Na}^{+}$ & 0.171 & $0.907^{* *}$ & $0.549 * *$ & $0.815^{* *}$ & 1 & $\mathrm{NH}_{4}{ }^{+}$ & & $\mathrm{Na}^{+}$ & 1 & -0.051 & -0.053 & 0.025 & 0.046 & 0.016 & $\mathrm{NH}_{4}{ }^{+}$ \\
\hline $\mathrm{NH}_{4}{ }^{+}$ & $0.498^{* *}$ & 0.206 & $0.782 * *$ & $0.629^{* *}$ & 0.232 & 1 & $\mathrm{~K}^{+}$ & & $\mathrm{NH}_{4}{ }^{+}$ & 1 & $0.661^{* *}$ & $0.666^{* *}$ & $0.654^{* *}$ & $0.665^{* *}$ & $\mathrm{~K}^{+}$ \\
\hline $\mathrm{K}^{+}$ & 0.073 & $0.405^{* *}$ & 0.010 & 0.000 & 0.117 & -0.019 & 1 & $\mathrm{Mg}^{2+}$ & & $\mathrm{K}^{+}$ & 1 & $0.989 * *$ & $0.989 * *$ & 0.990 ** & $\mathrm{Mg}^{2+}$ \\
\hline $\mathrm{Mg}^{2+}$ & 0.246 & $0.802 * *$ & $0.690^{* *}$ & $0.903^{* *}$ & $0.933^{* *}$ & $0.349^{* *}$ & -0.043 & 1 & $\mathrm{Ca}^{2+}$ & & $\mathrm{Mg}^{2+}$ & 1 & 0.988 ** & $0.999 * *$ & $\mathrm{Ca}^{2+}$ \\
\hline $\mathrm{Ca}^{2+}$ & 0.255 & $0.547^{* *}$ & $0.654^{* *}$ & $0.745^{* *}$ & $0.541^{* *}$ & $0.573^{* *}$ & 0.086 & $0.620^{* *}$ & 1 & nss-SO ${ }_{4}^{2-}$ & & $\mathrm{Ca}^{2+}$ & 1 & $0.987^{* *}$ & nss-SO ${ }_{4}{ }^{2-}$ \\
\hline nss-SO ${ }_{4}{ }^{2-}$ & $0.499^{* *}$ & $0.632 * *$ & $0.902 * *$ & $0.995^{* *}$ & $0.751 * *$ & $0.676^{* *}$ & -0.021 & $0.863^{* *}$ & 0.752 ** & 1 & nss- $-\mathrm{Ca}^{2+}$ & & nss-SO ${ }_{4}{ }^{2-}$ & 1 & nss-Ca ${ }^{2+}$ \\
\hline nss-Ca ${ }^{2+}$ & 0.251 & $0.484^{* *}$ & $0.632 * *$ & $0.701^{* *}$ & $0.468^{* *}$ & 0.579 ** & 0.078 & $0.558^{* *}$ & $0.996^{* *}$ & $0.715^{* *}$ & 1 & & & nss-Ca ${ }^{2+}$ & \\
\hline
\end{tabular}

** Significant at 0.01 level. * Significant at 0.05 level. 
PCA has been widely applied for precipitation chemical data analysis to identify possible pollutant sources and determine key relationships between variables $[9,20]$. The main ions in wet deposition can come from nature, anthropogenic or mixed origins, which are based on their source or precursor sources [50]. PCA of the main ions in wet deposition of northern Taiwan (Table 6) revealed that Wanli had two main component eigenvalues that were greater than 1 . They accounted for $91.43 \%$ of the total variance. Banqiao had three main component eigenvalues that were greater than 1 , and they accounted for $85.04 \%$ of the total variance.

Table 6. Factor analysis results of ions.

\begin{tabular}{cccccc}
\hline \multirow{2}{*}{ Variable } & \multicolumn{2}{c}{ Wanli } & \multicolumn{3}{c}{ Banqiao } \\
\cline { 2 - 6 } & Factor 1 & Factor 2 & Factor 1 & Factor 2 & Factor 3 \\
\hline $\mathrm{nss-SO}_{4}{ }^{2-}$ & 0.984 & -0.030 & 0.968 & -0.097 & -0.096 \\
$\mathrm{NO}_{3}{ }^{-}$ & 0.156 & 0.962 & 0.882 & -0.336 & 0.064 \\
$\mathrm{Mg}^{2+}$ & 0.979 & -0.129 & 0.879 & 0.314 & -0.288 \\
$\mathrm{CI}^{-}$ & 0.985 & 0.061 & 0.752 & 0.585 & 0.158 \\
$\mathrm{Na}^{+}$ & 0.981 & 0.037 & 0.807 & 0.518 & -0.176 \\
$\mathrm{NH}_{4}^{+}$ & 0.073 & 0.970 & 0.667 & -0.580 & 0.157 \\
$\mathrm{nss}^{+} \mathrm{Ca}^{2+}$ & 0.984 & -0.060 & 0.795 & -0.131 & 0.042 \\
$\mathrm{~K}^{+}$ & 0.737 & -0.140 & 0.089 & 0.424 & 0.875 \\
\hline Eigenvalue & 5.378 & 1.937 & 6.678 & 1.575 & 1.101 \\
Variance (\%) & 67.220 & 24.210 & 60.710 & 14.319 & 10.008 \\
\hline Possible source & Marine & Anthropogenic & Mixed & Marine & Crust \\
\hline
\end{tabular}

Wanli's first main component (Factor 1) accounted for $67.22 \%$ of the total variance. The high $\mathrm{Cl}^{-}, \mathrm{Mg}^{2+}, \mathrm{Na}^{+}$, and nss- $\mathrm{SO}_{4}{ }^{2-}$ and nss-Ca ${ }^{2+}$ loadings (>0.90) indicated they had the same source. In addition, the high $\mathrm{Cl}^{-}, \mathrm{Mg}^{2+}$, and $\mathrm{Na}^{+}$loadings indicated that the ocean was the main contributor. Moreover, $\mathrm{nss}^{-\mathrm{SO}_{4}{ }^{2-} \text { and nss-Ca }}{ }^{2+}$ were contributed by biological, crustal and anthropogenic sources crustal and anthropogenic sources. The second main component (Factor 2) accounted for $24.21 \%$ of the total variance. $\mathrm{NH}_{4}{ }^{+}$and $\mathrm{NO}_{3}{ }^{-}$had correspondingly high loadings $(>0.90)$. The $\mathrm{NH}_{4}{ }^{+}$ may have originated from agricultural, industrial, and transportation tool emission sources [34,51]. In cities, transportation tool emission was the main source of $\mathrm{NO}_{3}{ }^{-}[50,52]$. Thus, the possible sources for Wanli included marine sources and other anthropogenic emission sources (such as those from transportation tools).

The first factor for Banqiao (Factor 1) accounted for $60.71 \%$ of the total variance. Overall, $\mathrm{nss}^{-\mathrm{SO}_{4}}{ }^{2-}$ and $\mathrm{NO}_{3}{ }^{-}$had a high loading $(>0.90)$ and primarily came from human activity such as industrial and vehicle emissions [53]. The second main component (Factor 2) accounted for $14.32 \%$ of the total variance. $\mathrm{Na}^{+}$and $\mathrm{Cl}^{-}$both had high loadings $(>0.5)$ and possibly came from marine sources. Taiwan is an island that is surrounded by oceans, and thus marine sources play a major role. The third main component (Factor 3 ) accounted for $10.01 \%$ of the total variance. $\mathrm{K}^{+}$in Factor 3 had a higher loading (0.875). In urban areas, the biomass burning is a source of potassium $[9,54,55]$. Thus, Banqiao's wet deposition exhibited classic urban pattern sources. The sources of acidic ions were sulfates and nitrates that were the reactive products of anthropogenic emissions, such as sulfur oxides and nitrogen oxides. Acidic ions may have also been derived from some natural marine sources and biomass burning.

\section{Conclusions}

This study used the precipitation observation data collected in the Wanli and Banqiao over 12 months and their precipitation chemical properties to determine contribution sources of the atmospheric pollutants. The result against a background of Wanli facilitates a further insight into the impact of local and regional atmospheric pollutant distributions on urban and coastal area environments. The mean $\mathrm{pH}$ of wet disposition of this study was far lower than that of 10 East Asian regions (5.31). 
Wanli had a $\mathrm{pH}$ value of 4.63 , whereas Banqiao had a $\mathrm{pH}$ value of 4.58 . Acid rain frequency was $71.7 \%$ for Wanli and $85.1 \%$ for Banqiao, which signified that problems concerning acidic wet deposition in northern Taiwan remained severe. The total concentration of $\mathrm{SO}_{4}{ }^{2-}$ and $\mathrm{NO}_{3}{ }^{-}$in the study area is higher than the average of 10 East Asian regions, which may be the main reason. Sulfates and nitrates were the main substances that caused acid rain. These substances came from industrial activity and transportation and were mainly caused by anthropogenic activities.

The analysis results for ion composition and EFs suggested that $\mathrm{Cl}^{-}, \mathrm{Na}^{+}$, and $\mathrm{Mg}^{2+}$ are the main substances in Wanli's precipitation, and they accounted for $69.2 \%$ of the total ions. The $\mathrm{Na}^{+} / \mathrm{Cl}^{-}$ratio of 0.84 and $\mathrm{EF}_{\mathrm{m}}$ of 1.02 indicated that marine droplets were the main contributors of atmospheric substances, having an average SSF value of $\mathrm{Cl}^{-}$and $\mathrm{Na}^{+}$over $85 \%$. For Banqiao's precipitation, $\mathrm{Cl}^{-}, \mathrm{Na}^{+}$, and $\mathrm{Mg}^{2+}$ only accounted for $31.2 \%$ of the total ions because the amount of sea-salt ions decreased as the distance from the coast increased. Furthermore, $\mathrm{SO}_{4}{ }^{2-}$ and $\mathrm{NO}_{3}{ }^{-}$only accounted for $15.8 \%$ of the total ions in Wanli's precipitation but accounted for $32.4 \%$ in Banqiao's precipitation. Because $\mathrm{SO}_{4}{ }^{2-}$ and $\mathrm{NO}_{3}{ }^{-}$were produced by anthropogenic emissions, they were mainly related to industrial combustion and vehicle emissions. The high percentage of nss- $\mathrm{SO}_{4}{ }^{2-}$ and $\mathrm{NO}_{3}{ }^{-}$in Banqiao (average over $90 \%$ ) also showed the impact of rapid industrialization.

The FA, NF, and the acid/alkali balance ratio (NP/AP) revealed contribution of acidic substances and neutralizing compounds to the acidity of precipitation. The results indicated that the lack of neutralizing compounds in the study region's precipitation caused acidification because this reduced the neutralizing effect on acidic precipitation. For wet deposition in northern Taiwan, the ionizing acidity produced from nss- $\mathrm{SO}_{4}{ }^{2-}$ and $\mathrm{NO}_{3}{ }^{-}$exceeded the neutralizing reaction of neutralizing cations (such as ammonia ions). Furthermore, sulfuric acid had a greater impact on precipitation acidity than did nitric acid, which showed that the concentration and emission quantity of acid-causing substances and neutralizing compounds in the atmosphere, neutralization capability, were the main factors in the formation of acid rain in the study region.

The EFs, correlation, and PCA indicated that because of Wanli's geographical proximity to the coast and seasonal climate factors, its main source of pollution came from marine droplets. The emissions also contained other anthropogenic emission sources (such as from transportation tools). Banqiao is urbanized and has a high population density and high traffic volume, which resulted in industrial combustion and vehicle emission being the main emission sources. Banqiao's atmosphere was affected by local anthropogenic activities, and this effect was compounded by marine sources. This study discovered that precipitation chemistry was related to pollutant sources and transmission. The local and regional distributions of atmospheric pollutants were verified to exert different effects on coastal and urban cities. The precipitation chemical properties exhibited different characteristics in different regions and locations.

Author Contributions: Conceptualization, H.-Y.C. and L.-F.H.; methodology, L.-F.H. and L.Z.; software, L.-F.H. and S.-Z.H.; validation, H.-Y.C. and L.-F.H.; formal analysis, L.-F.H.; investigation, L.Z.; resources, H.-Y.C.; data curation, L.-F.H.; writing - original draft preparation, L.-F.H.; writing — review and editing, H.-Y.C.; visualization, S.-Z.H.; supervision, H.-Y.C.; funding acquisition, H.-Y.C. and L.Z. All authors have read and agreed to the published version of the manuscript.

Funding: This research was funded by The Ministry of Science and Technology of the Republic of China, grant number MOST 109-2611-M-019-009, and The Department of Environmental Protection, New Taipei City Government (Project No. 103-136).

Acknowledgments: The Ministry of Science and Technology of the Republic of China (grant MOST 109-2611-M-019-009) is acknowledged for the financial support. The research was also partly supported by the Department of Environmental Protection, New Taipei City Government (Project No. 103-136). Our special thanks to the editor and three anonymous reviewers for their helpful comments and suggestions.

Conflicts of Interest: The authors declare no conflict of interests. 


\section{References}

1. Khan, M.F.; Maulud, K.N.A.; Latif, M.T.; Chung, J.X.; Amil, N.; Alias, A.; Nadzir, M.S.M.; Sahani, M.; Mohammad, M.; Jahaya, M.F.; et al. Physicochemical factors and their potential sources inferred from long-term rainfall measurements at an urban and a remote rural site in tropical areas. Sci. Total Environ. 2018, 613, 1401-1416. [CrossRef] [PubMed]

2. Anil, I.; Alagha, O.; Blaisi, N.I.; Mohamed, I.A.; Barghouthi, M.H.; Manzar, M.S. Source Identification of Episodic Rain Pollutants by a New Approach: Combining Satellite Observations and Backward Air Mass Trajectories. Aerosol Air Qual. Res. 2019, 19, 2827-2843. [CrossRef]

3. Kulshrestha, U.C.; Kulshrestha, M.J.; Sekar, R.; Sastry, G.S.R.; Vairamani, M. Chemical characteristics of rainwater at an urban site of south-central India. Atmos. Environ. 2003, 37, 3019-3026. [CrossRef]

4. Chen, Y.X.; Chen, H.Y.; Wang, W.; Yeh, J.X.; Chou, W.C.; Gong, G.C.; Tsai, F.J.; Huang, S.J.; Lin, C.T. Dissolved organic nitrogen in wet deposition in a coastal city (Keelung) of the southern East China Sea: Origin, molecular composition and flux. Atmos. Environ. 2015, 112, 20-31. [CrossRef]

5. Anil, I.; Alagha, O.; Karaca, F. Effects of transport patterns on chemical composition of sequential rain samples: Trajectory clustering and principal component analysis approach. Air Qual. Atmos. Health 2017, 10, 1193-1206. [CrossRef]

6. Meng, Y.; Zhao, Y.L.; Li, R.; Li, J.L.; Cui, L.L.; Kong, L.D.; Fu, H.B. Characterization of inorganic ions in rainwater in the megacity of Shanghai: Spatiotemporal variations and source apportionment. Atmos. Res. 2019, 222, 12-24. [CrossRef]

7. Keresztesi, Á.; Birsan, M.; Nita, I.; Bodor, Z.; Szép, R. Assessing the neutralisation, wet deposition and source contributions of the precipitation chemistry over Europe during 2000-2017. Environ. Sci. Eur. 2019, 31, 50. [CrossRef]

8. Grennfelt, P.; Engleryd, A.; Forsius, M.; Hov, Ø.; Rodhe, H.; Cowling, E. Acid rain and air pollution: 50 years of progress in environmental science and policy. Ambio 2020, 49, 849-864. [CrossRef]

9. Chen, H.Y.; Chen, L.D. Importance of anthropogenic inputs and continental-derived dust for the distribution and flux of water-soluble nitrogen and phosphorus species in aerosol within the atmosphere over the East China Sea. J. Geophys. Res. 2008, 113. [CrossRef]

10. Zhou, X.D.; Xu, Z.F.; Liu, W.J.; Wu, Y.; Zhao, T.; Jiang, H.; Zhang, X.; Zhang, J.Y.; Zhou, L.; Wang, Y.C. Chemical composition of precipitation in Shenzhen, a coastal mega-city in South China: Influence of urbanization and anthropogenic activities on acidity and ionic composition. Sci. Total Environ. 2019, 662, 218-226. [CrossRef]

11. Smith, R.A. Air and Rain: The Beginnings of a Chemical Climatology; Longmans, Green, and Company: London, UK, 1872.

12. Galloway, J.N. Acidification of the World: Natural and Anthropogenic. Water Air Soil Pollut. 2001, 130, 17-24. [CrossRef]

13. EANET. Data Report on the Acid Deposition in the East Asian Region 2015. 2016. Available online: https://monitoring.eanet.asia/document/public/index (accessed on 13 December 2018).

14. Keene, W.C.; Pszenny, A.A.; Galloway, J.N.; Hawley, M.E. Sea-salt corrections and interpretation of constituent ratios in marine precipitation. J. Geophys. Res. Atmos. 1986, 91, 6647-6658. [CrossRef]

15. Kulshrestha, U.C.; Sarkar, A.K.; Srivastava, S.S.; Parashar, D.C. Investigation into atmospheric deposition through precipitation studies at New Delhi (India). Atmos. Environ. 1996, 30, 4149-4154. [CrossRef]

16. Al-Momani, I.F.; Güllü, G.; Ölmez, I.; Eler, Ü.; Örtel, E.; Sirin, G.; Tuncel, G. Chemical composition of eastern Mediterranean aerosol and precipitation: Indications of long-range transport. Pure Appl. Chem. 1997, 69, 41-46. [CrossRef]

17. Taylor, S.R. Abundance of chemical elements in the continental crust: A new table. Geochim. Cosmochim. Acta. 1964, 28, 1273-1285. [CrossRef]

18. Cao, Y.Z.; Wang, S.; Zhang, G.; Luo, J.; Lu, S. Chemical characteristics of wet precipitation at an urban site of Guangzhou, South China. Atmos. Res. 2009, 94, 462-469. [CrossRef]

19. Lu, X.; Li, L.Y.; Li, N.; Yang, G.; Luo, D.; Chen, J. Chemical characteristics of spring rainwater of Xi'an city, NW China. Atmos. Environ. 2011, 45, 5058-5063. [CrossRef]

20. Balasubramanian, R.; Victor, T.; Chun, N. Chemical and statistical analysis of precipitation in Singapore. Water Air Soil Pollut. 2001, 130, 451-456. [CrossRef] 
21. Possanzini, M.; Buttini, P.; Di Palo, V. Characterization of a rural area in terms of dry and wet deposition. Sci. Total Environ. 1988, 74, 111-120. [CrossRef]

22. Alagha, O.; Tuncel, G. Evaluation of air quality over the black sea major ionic composition of rainwater. Water Air Soil Pollut. Focus. 2003, 3, 89-98. [CrossRef]

23. Behera, S.N.; Sharma, M. Investigating the potential role of ammonia in ion chemistry of fine particulate matter formation for an urban environment. Sci. Total Environ. 2010, 408, 3569-3575. [CrossRef]

24. Chu, S.H. PM2.5 episodes as observed in the speciation trends network. Atmos. Environ. 2004, 38, 5237-5246. [CrossRef]

25. Lee, R.J.; Nicewander, W.A. Thirteen ways to look at the correlation coefficient. Am. Stat. 1988, 42, 59-66.

26. Jolliffe, C.; Cousins, L.; Javahery, G. Method and Apparatus for Detecting Positively Charged and Negatively Charged Ionized Particles. U.S. Patent 7,728,292, 1 June 2010.

27. Xu, Z.; Wu, Y.; Liu, W.J.; Liang, C.S.; Ji, J.P.; Zhao, T.; Zhang, X. Chemical composition of rainwater and the acid neutralizing effect at Beijing and Chizhou city, China. Atmos. Res. 2015, 164, 278-285. [CrossRef]

28. Huang, K.; Zhuang, G.; Xu, C.; Wang, Y.; Tang, A. The chemistry of the severe acidic precipitation in Shanghai, China. Atmos. Res. 2008, 89, 149-160. [CrossRef]

29. Tiwari, S.; Hopke, P.K.; Thimmaiah, D.; Dumka, U.C.; Srivastava, A.K.; Bisht, D.S.; Rao, P.S.; Chate, D.M.; Srivastava, M.K.; Tripathi, S.N. Nature and sources of ionic species in precipitation across the indo-gangetic plains, India. Aerosol Air Qual. Res. 2016, 16, 943-957. [CrossRef]

30. Al-Momani, I.F.; Ataman, O.Y.; Anwari, M.A.; Tuncel, S.; Köse, C.; Tuncel, G. Chemical composition of precipitation near an industrial area at Izmir, Turkey. Atmos. Environ. 1995, 29, 1131-1143. [CrossRef]

31. Al-Momani, I.F.; Tuncel, S.; Eler, Ü.; Örtel, E.; Sirin, G.; Tuncel, G. Major ion composition of wet and dry deposition in the eastern Mediterranean basin. Sci. Total Environ. 1995, 164, 75-85. [CrossRef]

32. Zhang, M.; Wang, S.; Wu, F.; Yuan, X.; Zhang, Y. Chemical compositions of wet precipitation and anthropogenic influences at a developing urban site in southeastern China. Atmos. Res. 2007, 84, 311-322. [CrossRef]

33. Xiao, J. Chemical composition and source identification of rainwater constituents at an urban site in Xian. Environ. Earth Sci. 2016, 75, 1-12. [CrossRef]

34. Szép, R.; Bodor, Z.; Miklóssy, I.; Niță, I.A.; Oprea, O.A.; Keresztesi, Á. Influence of peat fires on the rainwater chemistry in intra-mountain basins with specific atmospheric circulations (Eastern Carpathians, Romania). Sci. Total Environ. 2019, 647, 275-289. [CrossRef]

35. Yatkin, S.; Adali, M.; Bayram, A. A study on the precipitation in Izmir, Turkey: Chemical composition and source apportionment by receptor models. J. Atmos. Chem. 2016, 73, 241-259. [CrossRef]

36. Rao, P.S.P.; Tiwari, S.; Matwale, J.L.; Pervez, S.; Tunved, P.; Safai, P.D.; Srivastava, A.K.; Bisht, D.S.; Singh, S.; Hopke, P.K. Sources of chemical species in rainwater during monsoon and non-monsoonal periods over two mega cities in India and dominant source region of secondary aerosols. Atmos. Environ. 2016, 146, 90-99. [CrossRef]

37. Wu, Y.; Xu, Z.; Liu, W.; Zhao, T.; Zhang, X.; Jiang, H.; Yu, C.; Zhou, L.; Zhou, X. Chemical compositions of precipitation at three non-urban sites of Hebei Province, North China: Influence of terrestrial sources on ionic composition. Atmos. Res. 2016, 181, 115-123. [CrossRef]

38. Szép, R.; Mateescu, E.; Niță, A.; Birsan, M.V.; Bodor, Z.; Keresztesi, Á. Effects of the Eastern Carpathians on atmospheric circulations and precipitation chemistry from 2006 to 2016 at four monitoring stations (Eastern Carpathians, Romania). Atmos. Res. 2018, 214, 311-328. [CrossRef]

39. Zunckel, M.; Saizar, C.; Zarauz, J. Rainwater composition in northeast Uruguay. Atmos. Environ. 2003, 37, 1601-1611. [CrossRef]

40. Herut, B.; Starinsky, A.; Katz, A.; Rosenfeld, D. Relationship between the acidity and chemical composition of rainwater and climatological conditions along a transition zone between large deserts and Mediterranean climate, Israel. Atmos. Environ. 2000, 34, 1281-1292. [CrossRef]

41. Tiwari, S.; Chate, D.M.; Bisht, D.S.; Srivastava, M.K.; Padmanabhamurty, B. Rainwater chemistry in the North Western Himalayan Region, India. Atmos. Res. 2012, 104-105, 128-138. [CrossRef]

42. Harrison, R.M.; Pio, C.A. Size-differentiated composition of inorganic atmospheric aerosols of both marine and polluted continental origin. Atmos. Environ. 1983, 17, 1733-1738. [CrossRef]

43. Chate, D.M.; Devara, P.C.S. Acidity of raindrop by uptake of gases and aerosol pollutants. Atmos. Environ. 2009, 43, 1571-1577. [CrossRef] 
44. Roy, A.; Chatterjee, A.; Tiwari, S.; Sarkar, C.; Das, S.K.; Ghosh, S.K.; Raha, S. Precipitation chemistry over urban, rural and high altitude Himalayan stations in eastern India. Atmos. Res. 2016, 181, 44-53. [CrossRef]

45. Kumar, R.; Rani, A.; Singh, S.P.; Kumari, K.M.; Srivastava, S.S. A long term study on chemical composition of rainwater at Dayalbagh, a suburban site of semiarid region. J. Atmos. Chem. 2002, 41, 265-279. [CrossRef]

46. Seinfeld, J.H. Atmospheric chemistry and physics of air pollution. Environ. Sci. Technol. 1986, $20,863$. [CrossRef] [PubMed]

47. Niu, H.; He, Y.; Lu, X.X.; Shen, J.; Du, J.; Zhang, T.; Pu, T.; Xin, H.; Chang, L. Chemical composition of rainwater in the Yulong Snow Mountain region, Southwestern China. Atmos. Res. 2014, 144, 195-206. [CrossRef]

48. Rao, W.; Han, G.; Tan, H.; Jin, K.; Wang, S.; Chen, T. Chemical and Sr isotopic characteristics of rainwater on the Alxa Desert Plateau, North China: Implication for air quality and ion sources. Atmos. Res. 2017, 193, 163-172. [CrossRef]

49. Li, Y.C.; Zhang, M.; Shu, M.; Ho, S.S.H.; Liu, Z.F.; Wang, X.X.; Zhao, X.Q. Chemical characteristics of rainwater in Sichuan basin, a case study of Ya'an. Environ. Sci. Pollut. Res. 2016, 23, 13088-13099. [CrossRef]

50. European Environmental Agency (EEA). Air Quality in Europe-2015 Report; EEA: Copenhagen, Denmark, 2015.

51. Kim, M.K.; Lee, J.S.; Jung, G.B.; Ko, B.G.; Kwon, S.I.; Kim, M.Y.; So, K.H.; Yun, S.G. Chemical characterization of rainwater over Suwon region during farming and non-farming periods. J. Agric. Chem. Environ. 2013, 2, 1-7. [CrossRef]

52. Wang, H.; Han, G. Chemical composition of rainwater and anthropogenic influences in Chengdu, Southwest China. Atmos. Res. 2011, 99, 190-196. [CrossRef]

53. Tiwari, S.; Srivastava, M.K.; Bisht, D.S. Chemical composition of rainwater in Panipat, an industrial city in Haryana. Indian J. Radio Space Phys. 2008, 37, 443-449.

54. Lara, L.B.; Artaxo, P.; Martinelli, L.A.; Victoria, R.L.; Camargo, P.B.; Krusche, A.; Ayers, G.P.; Ferraz, E.S.B.; Ballester, M.V. Chemical composition of rainwater and anthropogenic influences in the Piracicaba River Basin, Southeast Brazil. Atmos. Environ. 2001, 35, 4937-4945. [CrossRef]

55. Budhavant, K.B.; Rao, P.S.P.; Safai, P.D.; Ali, K. Influence of local sources on rainwater chemistry over Pune region, India. Atmos. Res. 2011, 100, 121-131. [CrossRef] 